\title{
Viimsetest sõnadest meediaajastul
}

\author{
Karl Siegfried Guthke
}

\begin{abstract}
Teesid
Meie ajal on "viimsete sõnade institutsioon" (Dennis Joseph Enrighti termin), mille kohaselt avaldavad inimese viimsed surmaeelsed sõnad kõige ilmsemalt tema verbaalset tahet, kaotanud suurema osa oma religioossest sisust. Kuid need on jäänud jätkuvalt igapäevasesse pärimusse (haritlaste folkloori), leidnud vastuvõtliku pinnase meedias, filmides, reklaamis, poplauljate repertuaaris, koomiksites, kunstnike show'des, joonisfilmides, ajalehtedes (tuntud inimeste järelehüüetes, nn inimliku huvi lugudes, hukkamiste, suurõnnetuste ja mõrvade reportaažides jne).

Märksõnad: haritlaste folkloor, meediakultuur, pop-lore, viimsed sõnad.
\end{abstract}

Picasso oli parajasti lahkumas, kui Isaiah [Berlin] talle lähenes ja hakkas jutustama lugu Lope de Vega surivoodil lausutud viimsetest sõnadest. ["Igatahes Dante tüütab mind."] Tagajärjed olid katastroofilised. Isaiah' edasi heietades süngestus Picasso ilme. Surm oli Picasso juuresolekul rangelt keelatud teema; lugu kuulsa hispaanlase surmast oli veelgi halvem ja kõige hullem oli lugu, milles ilmselgelt naeruvääristati hispaanlasest kunstniku viimseid sõnu. Picasso tormas välja ja tema suur Mercedes kihutas öhe. Isaiah aga jäi nõutult maha, mõistmata, mida ta valesti oli teinud (Ignatieff 1998: 218).

Printsess Diana hukkumisele liiklusõnnetuses järgnes otsekohe teinegi sensatsioon: Dodi al-Fayedi isa Mohammed al-Fayed teatas intervjuus, nagu oleks Diana Pariisi haiglas enne surma oma viimsete sõnadega ühele meditsiiniõele väljendanud testamendilaadset soovi, et tema õde Sarah päriks kogu tema Dodi korteris oleva isikliku vara, riided, ehted ja muu ning võtaks oma hoole alla tema lapsed. Kuigi nii Buckinghami palee kui ka Diana perekond lükkasid selle väite mõistagi ümber, jooksis vastav teade siiski maailma ajakirjandusest läbi, New York Times (1998, 15. veebruar, 1. osa:4) kaasa arvatud, ja veel 1998. aasta suvel oli Diana vend krahv Spencer sunnitud televisioonis eitama isegi oma õe viimsete sõnade pelka võimalikkust (24. juuni, BBC 1, My Sister Diana, kl 20). Kas selliseid kuuldusi põhjustab tõik, et mõned teoloogid väidavad tänani, nagu satuks hing, mis lahkub vagade viimsete sõnadeta, otseteed põrgusse, mida ka 1998. aasta 19. augusti Londoni Timesist (lk 5) võiski seoses Dianaga lugeda?

http://haldjas.folklore.ee/tagused/nr25/guthke.pdf 


\section{Karl Siegfried Guthke}

Sellelaadsete juhtumustega seoses annab endast märku aastasadu vana kultuuritraditsioon või ka kultuuri "institutsioon" (Dennis Joseph Enright'i termin), mis Johann Wolfgang von Goethele oli veel sedavõrd enesestmõistetav, et ta võis näiteks Fausti kirjutades oma lugejailt eeldada, et need teavad, mida varakristliku ajajärgu suur patustaja ja patukahetseja Egiptuse Maria testamendina kõrbeliivale kirjutas (värss 12053 jj). ${ }^{1}$ Kuigi selline viimsete sõnade kultuur näib tänapäeval olevat ammu unustusehõlma vajunud (ehkki me kõik viimseid sõnu teame), ümbritseb see meid argielus siiski igal sammul ja iseäranis kokkupuutes meediakultuuriga. Aga kus seda pole! Jaa, meie aeg on viimsete sõnade kultuuri isegi mõningate progressiivsete elektrooniliste väljendusviiside võrra rikastanud: teada on juhtumeid oma hüvastijätukirja isiklikule kodulehele üles riputanud enesetapjatest, samas kui UFO kultusrühma Heaven's Gate massienesetapu ohvrid lasid oma viimsed sõnad videosse võtta (New York Times 1996, 15. juuli: A7; 1997, 29. märts, 1. osa: 8).

Sisuldasa võivad sellised ajalehtedesse sokutatud hüvastijätuavaldused tunduda mõnele lugejale triviaalsed, kuid need pretendeerivad siiski, ja tihti koguni pühalikult, õilsale õigusele olla inimelu kokkuvõte ja elutarkuse väljendus. Seetõttu käituvad nad kui viimsete sõnade kultuuri seaduslikud järeltulijad, kultuuri, mis on oma seaduspärasust formuleerinud kõige sagedamini just saksa keeles. Friedrich Nietzsche pidas neid kurja selgepilgulisusega kristluse loomuomaseks väljenduseks, kui ta laimas teoses Vom Nutzen und Nachteil der Historie für das Leben (Ajaloo kasust ja kahjust elule), mis pärineb aastatest 1873-1876, poleemilise vaimustusega kristlust eluvaenulikuks, märkides, et see olevat religioon, mis peab inimelu kõigist tundidest olulisimaks viimset [ja selle kaudu ka viimseid sõnu] (8. ptk; vt nt Nietzsche 1949). Ajalooliselt polegi see väär, kui mõelda kogu "suremiskunstile" (Sterbenskunst) ja arvukatele saksakeelsetele kristlike viimsete sõnade antoloogiatele, aga ka põhiosas luterlikule matusekõnede traditsioonile, mis igal võimalikul juhul viimsed sõnad jutuks võtab, nagu tõestab ilmekalt Wolfenbütteli (asub Hertsog Augusti raamatukogus (Herzog-August-Bibliothek) - toim) vastavate jutluste kogu (Sammlung der Leichenpredigten). Ometi on just saksakeelsed intellektuaalid sõnastanud ammustest aegadest surmakogemuse ja seda väljendavate viimsete sõnade müstikat pigem ilmalikes seostes. Christian Friedrich Hebbeli sõnad tema päevaraamatus on seejuures veel tagasihoidlikud: 
Inimene, kes on lõiganud läbi oma veresoone, peaks kirjutama raamatu vaimse elu järkjärgulisest kustumisest iseendas, oma viimsetest mõtetest ja muust (Hebbel 1908: $\mathrm{nr}$ 3046).

Jena romantikute Novalise ja Friedrich Schlegeli suhtluskonda kuulunud füüsiku Johann Wilhelm Ritteri Fragmentidest seevastu pärineb väljaspool romantismi mõistetamatuks jääv paradoks: Elavaks saadakse surres (Ritter 1810: nr 697). Friedrich Wilhelm Joseph von Schellingki ei jõudnud tervele inimmõistusele lähemale, väites: Meie seisukohalt on olemise kõrghetk üleminek mitteolemisse, hävitusmoment (Schelling 1856: 324). Uuemal ajal on isegi muus osas vastakaid vaateid esindavad Walter Benjamin ja Ernst Bertram olnud ühel nõul selles, et alles surmaga silmitsi seistes muutub inimelus sisalduv tõde verbaalselt edasi antavaks, täpsemalt arusaadavaks (Benjamin 1977: 449-450; Bertram 1934: 166-167). Nimetatud küsimuses on kokkuleppel isegi Hugo von Hofmannstahl (kelle surev Tizian värssdraamast Tiziani surm kogeb enneolematut selgust; Hofmannstahl 1982: 42²) ja Berthold Brecht, kes väidab luuletuses "Alles wandelt sich" ("Kõik muutub"), et neu beginnen kannst du mit dem letzten Atemzug (sa uuesti saad alata viimse hingetõmbega).

Need meelevaldselt välja otsitud tsitaadid selgitavad, kuidas saksa hääled, kuigi pisut pateetiliselt, ühinevad nende kooriga, kes on veendunud, et elu lõpuhetkel lausutud sõnad on tõe ja tarkuse poolest kaalukamad kui mis tahes eelnevalt välja öeldud mõtted. See on pika ja kireva ajalooga Euroopa (ja mitte ainult Euroopa) koor, millest teised sub- ja erikultuurid 20. sajandil ehk sageli üle kostavad, kuid mis on kahtlemata senini selgelt kuuldav. Näiteks kõlab see koor vastu õitsval järjel olevast tanatoloogiast (Herman Feifeli käsiraamatus The Meaning of Death (Surma tähendus) on kirjas: A man's birth is an uncontrolled event in his life, but the manner of his departure from life bears a definite relation to his philosophy of life and death (Inimese sünd on kontrollimatu sündmus tema elus, kuid tema elust lahkumise viis on selgelt seotud tema elu-ja surmafilosoofiaga) (Feifel 1959: 128)), kirjanduslikust esseistikast (David Herbert Lawrence (1978: 676): We understand our extreme being in death... (Oma lõplikku olemasolu mõistame surmas...)) ja igapäevasest sõnapruugist (näiteks melodramaatiline eneselavastamine selliste fraasidega nagu Stephen Spenderi mälestusraamatu (1951: 18) järgi ta isa armastatud: These are the words of a dying man (Need 


\section{Karl Siegfried Guthke}

on sureva mehe sõnad), rääkimata väljenditest kein Sterbenswort sagen (eesti vaste: mitte sõnagi lausuma), das letzte Wort haben ([talle] peab jääma viimane sõna, [tema] sõna peab peale jääma) jms.

Kuid antiiki, Vana Testamendi ja rooma-germaani aegadesse tagasiulatuv, puritaanses kultuuris, kuid ka veel 19. sajandil erakordselt levinud viimsete sõnade kultuur, ${ }^{3}$ mis peab viimset verbaalset väljendust tõelise Mina testamendilaadseks avalduseks, näitab tänapäeval jõulisi elumärke kõikvõimalikes meediumides, kuuludes seega nn popkultuuri, kusjuures mitte üksnes noorte omasse. Selle manifestatsioonid ulatuvad Paul McCartney biitšlaagrist Picasso's Last Words (Piccasso viimsed sõnad) triviakalendrite (Trivia Calendar), Trivial Pursuiti laadsetest viktoriinlauamängudest ristsõnade, reklaamist mängu-ja dokumentaalfilmide, koomiksitest nekroloogide ning verivärsketest hukkamisteadetest ajalehtedes iga taseme kriminaalromaanideni. ${ }^{4}$ See on kultuur, mis tänapäeval tunneb end koduselt eelkõige ingliskeelses maailmas, kuid on levinud ka kogu saksakeelses meedias ja sugugi mitte ainult ingliskeelse järelkajana. Näiteks teatab ajaleht Neue Züricher Zeitung 1992. aasta 16. septembri numbri seitsmendal leheküljel pealkirja all "Kuningas Georg V viimsed sõnad" Briti ajaloolaste pika teadusliku vaidluse lõppemisest ja järeldusest, et majesteetlik-imperialistliku valitseja viimsed sõnad polnud mitte How is the Empire? (Kuidas läheb impeeriumil?), nagu kinnitavad kooliõpikud, vaid oma jämeda vulgaarsuse tõttu tõlkimatu hü̈̈atus. Samas ilmub ajakirjanduses aga ka algupäraseid, saksa ainesel põhinevaid selleteemalisi käsitlusi, nagu Die Zeitis avaldatud kirjutis Saksa Wehrmachti ohvitserist, kes käsu täitmisest keeldudes hoidis 1945. aastal ära Gotha linna hävitamise: Ehre dem Retter: Die letzten Worte des Offiziers: 'Damit Gotha leben kann, muß ich sterben' (Au päästjale: Ohvitseri viimsed sõnad: "Et Gotha jä̈̈ks ellu, pean mina surema”; Die Zeit 1997, 29. august: 16). Hannah Arendti 1996. aasta maikuu Merkuris avaldatud kirjutis Adolf Eichmanni hukkamisest seevastu hoidub äärmustest ja on samas omapäraseks näiteks viimsetele sõnadele omistatavast üldistusjõust:

See kohutav anne ennast stampidega lohutada ei jätnud teda [Eichmanni] maha isegi surmatunnil. Vôlla all seistes selgitas ta oma viimsetes sõnades alustuseks, et ta olevat jumalausklik (gottgläubig), mis natside keelepruugis tähendas, et ta 
ei olnud kristlane ega uskunud elusse pärast surma. Ja jätkas seejärel: "Varsti, mu härrad, näeme üksteist jälle. See on kõigi inimeste saatus. Elagu Saksamaa, elagu Argentiina, elagu Austria! Ma ei unusta neid."

Surma palge ees seistes ei meenunud talle muud kui see, mida ta arvukates matusekõnedes oli kuulnud. Võllase ootuses mängis mälu talle viimse vembu, ta tundis end ülevalt nagu matustel, unustades, et tegemist oli tema enda matustega. Nendel viimsetel minutitel oli, nagu teeks Eichmann ise kokkuvõtteid pikast inimliku julmuse õppetunnist, mille juures olime viibinud; kokkuvõtte kurjuse kohutavast banaalsusest, millega põrkudes purunevad nii sõna kui ka mõte (Arendt 1996: 426; esmatrükk Merkuri 1963. aasta augustinumbris).

Viimsete sõnade kultuuri muudab eriti meediasõbralikuks asjaolu, et viimsed sõnad tõusevad sageli lendsõnade staatusesse. Ka see, kes pole iial lugenud ainsatki J. W. v. Goethe kirjutatud rida, on kuulnud, et ta lahkus siitilmast sõnadega Rohkem valgust! (Mehr Licht!), märkis üks ameeriklane aastakümneid tagasi (Le Comte 1955: vii; Guthke 1992: 16, 18, 885). Samuti on need öeldavasti erakordselt sümboolsed viimsed sõnad juba ammu jäänud hambusse naljahammastele rahvasuust (Mer liecht nix mehr am Lewe (tõlge vanast saksi murdest: Ma ei taha enam elada - toim); Parth 1981: "Viimsed sõnad") Theodor Haeringini:

Wenn er's erlebt noch hätte,

Der längst nun lebt im Licht,

Er spräche vom Sterbebette

Nur müde noch: "Mehr nicht"6 (Schoeps 1971: 261).

Günter Kunertsi luuletusest "Mehr Licht" ("Rohkem valgust"):

Das Gesicht zur Wand gekehrt

Goethe auf dem Sterbebett

Man hört nur das Kratzen

der Fingernägel

die Suche nach dem geheimen Türgriff

in eine Künftigkeit

die dunkler sein wird

als wäre ich dabei gewese (Kunert 1996: 30) 


\section{Karl Siegfried Guthke}

F. W. Bernsteini (Fritz Weigle) värssideni "Hosenscheißer" ("Püksisittuja"):

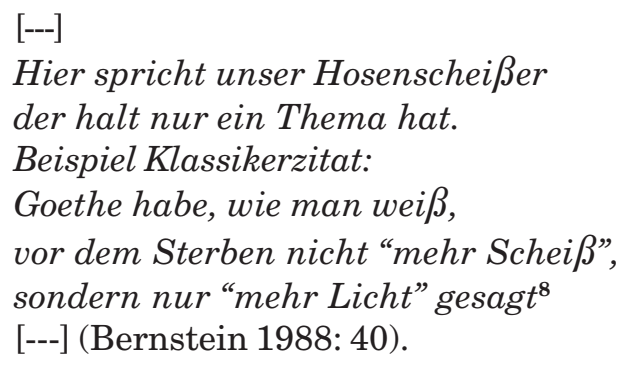

Lisaks Thomas Bernhardi "Behauptung" ("Väide") teosest Der Stimmenimitator (Hääleimitaator):

Üks Augsburgi mees toimetati pelgalt sellepärast kohalikku hullumajja, et ta kogu elu igal võimalikul juhul väitis, nagu oleks Goethe viimsed sõnad olnud mehr nicht! [mitte rohkem!], mitte mehr Licht! [rohkem valgust!], mis hakkas kõigile temaga kokku puutunud inimestele pikapeale niivõrd närvidele käima, et nad ühendasid jõud eesmärgiga saavutada selle oma väitest nii õnnetul kombel justkui kurjast vaimust vaevatud augsburglase hullumajja paigutamine. Kuus arsti olevat õnnetule hullupaberite andmisest keeldunud, seitsmes aga kirjutas need otsekohe välja. Nagu ma Frankfurter Allgemeine Zeitungist teada sain, autasustati seda arsti selle eest Frankfurti linna Goethe aurahaga (Bernhard 1978: 58).

Sama levinud ja üldtuntud on Georg V viimsed sõnad (mõlemas variandis). Kunagi võib ehk sama öedla ka Rudi Dutschke kohta, kelle viimseid sõnu (Vater. Mutter. Soldaten! (Isa. Ema. Sõdurid!)) meenutas Wolfgang Büscher (1998: 91) oma raamatus Drei Stunden Null: Deutsche Abenteuer (Kolm tundi nullseisu: Saksa seiklused). Ameerikas kuuluvad sellesse kategooriasse mõnede presidentide viimsed lausungid. Seejuures tuleb märkida, et USAs leidub tõsiseid ajalooteatmikke Facts About the Presidents (Fakte presidentide elust), mis ei sisalda üksnes iga presidendi eludaatumeid ja poliitilise karjääri verstaposte, vaid ka nende viimseid sõnu (vt nt Kane 1981: 374). Iga gümnasist teab elupõliste rivaalide Thomas Jeffersoni ja John Adamsi mälestusväärset ja mitmes mõttes sisukat duetti. 
Mõlemad surid 4. juulil 1862: T. Jefferson Virginias pärast ennelõunal kõlanud viimset küsimust Is it the Fourth? (Kas täna on neljas?), samas kui J. Adams lahkus Massachusettsis viis tundi hiljem, tõdedes Thomas Jefferson survives (Thomas Jefferson elab edasi).

Kuid mitte ainult ajalugu, vaid ka kirjandus (isegi lastekirjandus $)^{9}$ pakub selliseid lendsõnu, mida algselt on kuuldud surija huulilt (Guthke 1992: 29-66; teiste näidete kohta Guthke 1990: 35-55), nendest on saanud haritlaste pärimus. Saksa lugejale meenub siinkohal kõige tõenäolisemalt Friedrich Schilleri ballaad Die Kraniche des Ibikus (Ibikuse kured; vt nt Schiller 1924 (saksa k); 1959: 24-29 (eesti k) - toim) ja või tema tragöödia Wallenstein (vt nt Schiller 1993 \& 1994 (saksa k) - toim) nimikangelase sõnad Ich denke einen langen Schlaf zu tun (Ma kavatsen jääda pikale unele), kuid mitte Karl Moor (Schilleri näidendist Röövlid - toim), kelle viimseks ohkeks oli Franz Moori sõnul nimi: Amalia (vt nt Schiller 1962 (saksa k); 1960 (eesti k) - toim). Kõige huvitavam on tänapäevases kontekstis tõik, et sageli on just meedia usaldusväärseim tsitaadile lendsõna staatuse omistamisel. Nii viitas uudisteajakiri Newsweek oma aastalõpunumbri (26. detsember 1994 - 2. jaanuar 1995) rubriigis "Periscope" Marlon Brando septembris ilmunud autobiograafia sensatsiooniliselt kehvale müügiedule - isegi aastavahetuse eel müüdi seda allahinnatult - sõnadega: The horror! The horror! ${ }^{10}$ Igasugused lähemad kommentaarid puuduvad, ka ei peeta vajalikuks täpsustada, et tegemist on kaubaagent Kurtzi üldtuntud viimsete sõnadega Joseph Conradi romaanist Pimeduse süda (The Heart of Darkness ${ }^{11}$ ), mis on meie kõige multikultuurse suhtes erksas olevikus omandanud erilise aktuaalsuse. (Ka Alex Garlandi kultusromaanis Rand $^{12}$ (The Beach) aastast 1996 esines nimetatud fraas samasuguse kommentaarideta enesestmõistetavusega, millele The London Review of Books (15. oktoober 1998, lk 36) ka tähelepanu juhtis.) Sama lootusrikkalt arvestab viimsete sõnade lennuka staatusega Francis Spuffordi (1997) polaaralade avastamise ajalugu käsitleva raamatu pealkiri I May be Some Time (Mul võib pisut aega minna). Need on Robert Scotti lõunapooluse-ekspeditsiooni liikme John Oatesi viimsed sõnad. R. Scotti päeviku kohaselt pidi J. Oates aimama, et kahanevatest varudest ei piisa kõigile neljale meeskonnaliikmele, ja ta ohverdas enda, astudes telgist välja mässavasse lumetormi sõnadega: I'm just going outside and I may be some time (Ma lähen praegu välja ja mul võib pisut aega minna). Saab näha, kas ka John Updike'i erakordselt eduka mitmeköitelise Rabbiti- 


\section{Karl Siegfried Guthke}

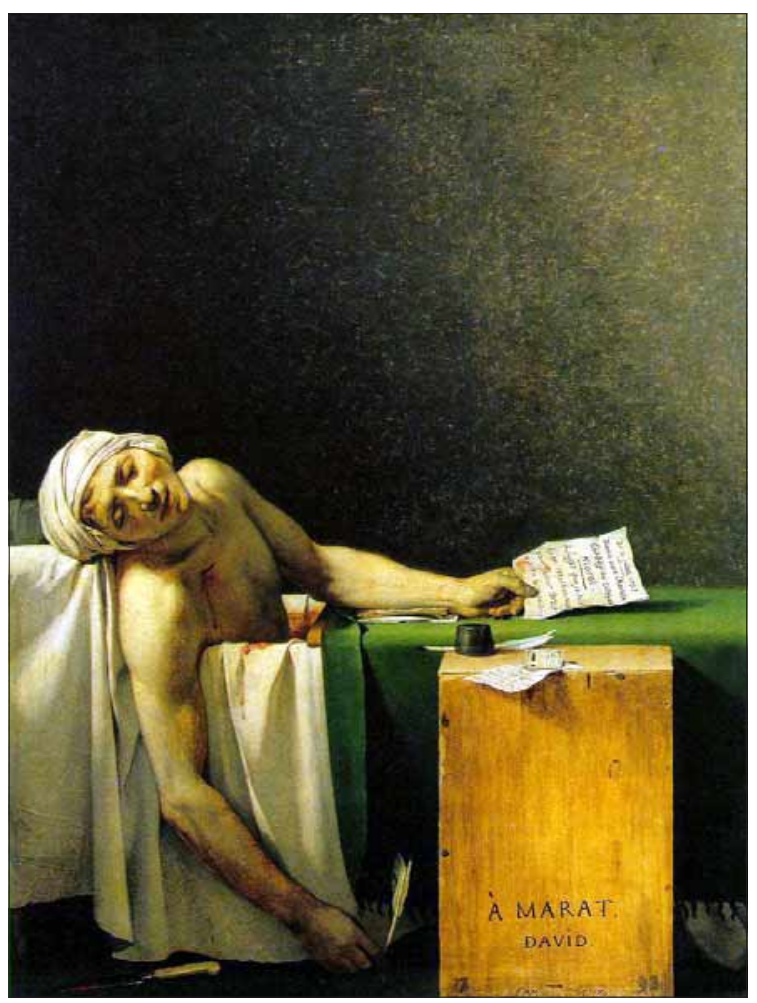

Foto 1. Jacques Louis David (1748-1825). Marat' surm (1793; ôli, lõuend). Repro.

tetraloogia (vt nt Updike 1995 - toim) peategelase viimsed sõnad lausutud pärast 1500 lehekülge kestnud ootamist ja oma banaalsuses ületamatud - All I can tell you is, it isn't so bad (Kõik, mis ma võin teile öelda, on, et see ei ole nii hull) kui küüniline kokkuvõte ameerikalikust kultuurist jõuavad kunagi samasugusesse lendsõna staatusse.

Viimsete sõnade meediasõbralikeks lendsõnadeks kanoniseerimise katalüsaatoriteks on viimsete sõnade antoloogiad. Kõikvõimalikel valikupõhimõtetel koostatuina (kristlikud, vabamõtlejalikud, ajastute, elukutsete, klasside, surmapõhjuste või viimsete sõnade laadi järgi) on neid välja antud juba aastasadu ning nad täidavad ka erinevaid funktsioone, pakkudes pikantset meelelahutust, biograafilisi seletusi, elujõudu ja hingekosutust (mille juures nen- 
de puritaanlik-kristlik variant võib - Joseph Addisoni vanasõnaks muutunud, kaalutletult lavastatud viimsed sõnad See how a Christian can die (Näete, kuidas kristlane võib surra) - muutuda stoilis-humanistlikuks, nagu Ben Jonsoni leedi Jane Pawletile pühendatud eleegias, kes in her last act, taught the Standers-by, / With admiration, and applause to die! ${ }^{13}$ (Hunter 1963: 249). Tänapäeval õitseb viimsete sõnade antoloogia žanr nagu ei kunagi varem ja neid võib osta näiteks jaamakioskist rongi oodates. Samas on teada ja isegi meediast läbi jooksnud, et selline intellektuaal nagu Ernst Jünger pole kogunud ja pedantselt katalogiseerinud mitte ainult sitikaid, vaid ka viimseid sõnu, kommenteerides neid viimsete sõnade kultuuri ja selle ootuste läve seisukohalt. ${ }^{14}$ Lõpuks on ükskõik, kas sellised kompendiumid on taskuraamatu formaadis, nagu Herbert Nette Hier kann ich doch nicht bleiben (Ma ei saa ju siia jääda; 1983) ja neid loetakse trammis sõites, või laenutatakse neid väärikast ülikooliraamatukogust - mõlemad juhud on ilmselged tõestused viimsete sõnade igapäevasest kohalolust. Pole ime, et veel 1990. aastatel tuleb turule üha uusi surijate sõnade antoloogiaid (vrd Guthke 1992: IV ptk; teisi antoloogianäiteid: Donald Sindeni The Last Words (Viimsed sõnad; 1994 - mõeldud meelelahutusena); Susan Bergmani (1997) A Cloud of Witnesses. Twentieth Century Martyrs (Hulk tunnistajaid: Kahekümnenda sajandi märtrid - ajalooline pealkiri!)) üha uute variantidena: ingliskeelsetest näidetest olgu nimetatud Dorsey Scotti Famous Last Words (Kuulsad viimsed sõnad; 1992) ja C. Bernard Ruffini Last Words (Viimsed sõnad; 1995), prantsuskeelsetest Martine Courtois' Les mots de la mort (Surmaeelsed sõnad; 1991) ja Isabelle Bricard'i Dictionnaire de la mort des grands hommes (Suurmeeste surmade entsüklopeedia; 1995). Juhtudel, mil neis teostes kommenteeritakse viimseid verbaalseid elumärke, käsitletakse neid lõppenud elu kohta antud tunnistuse, tõe pitserina. (Erandid torkavad vastava kultuuri tundjale silma selle poolest, et need tuuakse eraldi esile. ${ }^{15}$ )

\section{II.}

Viimsete sõnade popkultuuri vahendajate ja säilitajatena toimivad tänapäeval ühtaegu eelkõige massilevikuga päevalehed ja ajakirjad kuni lennukite pardaajakirjadeni välja, seda eriti väljaande igapäevaste rubriikide ja teemablokkide kaudu. Isegi koomiksid po- 


\section{Karl Siegfried Guthke}

leks viimsete sõnadeta mõeldavad (vrd Guthke 1992: 15) (kui koomiksikangelane Superman 1993. aasta jaanuaris pärast kahevõitlust kaabakas Doomsdayga siitilmast lahkus, oli tema viimseks küsimuseks, kas Doomsday ehk siis kuri maailmas on surnud; sellele kinnitust saanult võis ka tema rahulikult heita oma õilsa superhinge (75. osa)). Ka osale lugejatest elutähtsad ristsõnad ei saa hakkama viimsete sõnadeta, mis viitab kõnealuste väljendite vanasõnalikkusele (New York Times 1993: 16. veebruar; 1994: 1. august). Loomulikult ei tohi unustada reklaami (vrd Guthke 1992: 15). ${ }^{16}$ Kui varsti pärast Richard Nixoni surma ilmus tema viimane raamat Beyond Peace (Rohkem kui rahu), esitles uudisteajakiri Times (1994, 2. mai: 30 jj) seda kui His Final Words (Tema otsustavad sõnad), samal ajal kui New York Times (1994, 26. aprill: A24) kasutas terve lehekülje enda alla võtnud pealkirja Nixon's Last Words (Nixoni viimsed sõnad), lootes "institutsiooni" külgetõmbejõule.

Ajalehtede kui uudisväärtusega teabe vahendajate rubriikide raudvarasse kuuluvad ka järelehüüded. Pole meediastaari, kes lahkuks elust nekroloogilise aplombita - selle eest hoolitsevad ühiselt nii ajakirjanikud kui ka mahajääjad, kellele oleks surm viimsete sõnadeta pettumus, et mitte öelda postuumne häbi. (Pancho Villa verekaotusesse suremisest rääkides meenutatakse, et ta olevat viimse hingetõmbega ennast ümbritsenud ajakirjanikele sosistanud ja vähemalt üks triviakalender on sellest juba kinni haaranud - , et nad ei tohiks lasta asjal niiviisi lõppeda, vaid peaksid oma lugejatele teatama, et ta siiski ütles midagi (Guthke 1992: 10, 15, 150). ${ }^{17}$ ) Ka ei jätnud hiljuti ajalehe- ega raadiouudised, Internetist rääkimata, edastamata tänuväärsele publikule Frank Sinatra viimseid sõnu, mida tema tütar kuulis isa surmahetkel haiglas valves olnud meditsiiniõelt: I'm losing it (Kõik on kadunud). See banaalne ameerika kõnekäänd, mis, nagu mõni pieteedi- ja kaastundetu kaasaegne võib-olla juurde lisaks, ei kõla sellega lõppenud elu kohta kaugeltki kohatult (People [Magazine] Online Daily 1998, 19. mai). Dr Howard Bruenni nekroloogi poleks aga New York Times (1995, 2. august: D20) ehk avaldanudki, kui tema poleks olnud see arst, tänu kellele mäletab maailm senini Franklin D. Roosevelti paljukommenteeritud viimseid sõnu: I have a terrific headache (Mul on kohutav peavalu). Dr H. Bruenni järelehüüdes rõhutatakse seda fakti, justkui oleks see olnud kadunu ainus elusaavutus! Tema enda viimsetest sõnadest aga ei silpigi. 
Kui väga viimseid sõnu isegi tänapäeval veel nimelt lavastada armastatakse - üks viimsete sõnade kultuuri silmapaistvamaid aspekte (Guthke 1992: 25-26) - , tuleb välja taas New York Timesis ilmunud järelehüüdest kuulsale matemaatikageeniusele Paul Erdösile:

Ta tavatses fantaseerida täiuslikust surmast. See saabuks just pärast loengut, kui ta oleks just lõpetanud tõestuse esitamise ja mõni norimishimuline kuulaja oleks tõstnud käe küsimaks: “Aga mis sellest järeldub?” Vastuseks, tavatses dr Erdös öelda, oleks ta lausunud: "Ma arvan, et jätan selle järgmise põlvkonna selgitada," ja surnult maha varisenud.

Dr Erdös ei suutnud küll oma ettekujutust täiuslikust surmast päriselt realiseerida, ütles dr Graham, kuid jõudis sellele üsna lähedale.

"Ta suri jalapealt, maadeldes järjekordse probleemiga,"lausus dr Graham. "Just nii tahtis ta lahkuda"18 (New York Times 1996, 24. september: B8).

Oma surma lavastamine (reformatsiooniaegsetele puritaanidele veel tuttav ja jumalale meelepärane kohustus ellujääjate hingekosutuse tagamiseks, tänapäeval pigem ammendamatu naljade ja karikatuuride allikas, eriti New Yorkeris (Guthke 1992: 8)) õnnestus rokkmuusikast ja uimastitest läbiimbunud 1960. aastate psühhodeelsete kollektiivekstaaside gurul Timothy Learyl. Kui T. Leary 1996. aasta varasuvel surivoodil vaevles, oli ta eelnevalt hoolt kandnud, et tema lahkumine võetaks videosse võimalikuks Internetis edastamiseks $^{19}$ (isegi meie päevil, mil surm on muutunud suuresti tabuteemaks, on sedalaadi vaatamisvara vahetevahel ka televisioonis näidatud $^{20}$ ). Tulemus polnud just vapustav. Üks sõber teadis rääkida, et T. Leary olevat oma viimsel õhtul öelnud: Don't let it be sad. Buy wine. Put soup on the stove (Ära kurvasta. Osta veini. Pane supp sooja), millest ta järeldas: Tim loved life (Tim armastas elu). Ühe sõbranna sõnul olid aga T. Leary viimsed sõnad: Why not? Why not? Why not? (Miks mitte? Miks mitte? Miks mitte?). Ta oli ju alati ennast korranud ja võib-olla pidaski tema kasupoeg just seda silmas, kui andis maailmale New York Timesi (1996, 1. juuni, 1. osa) esiküljel teada, et until the end he was maintaining his rascal quality ( ta jäi elu lõpuni võrukaelaks). Teated T. Leary viimsete sõnade kohta muudab huvitavaks just inimajusse sügavalt juurdunud sundus ot- 


\section{Karl Siegfried Guthke}

sida viimsete sõnade elu avavat, kokkuvõtvat tähendust ja sügavamõttelisust.

Uuematest sellekohastest meedianäidetest parim on helilooja ja dirigendi Leonard Bernsteini surm. Newsweek pühendas talle poolteiseleheküljelise mälestusartikli, mis lõppes mitte lihtsalt tema viimsete sõnade, vaid nende tõlgendusega tagasivaatena elule, mille nad lõpetasid erakordselt läbimõeldult, nii et selle võiks kokku võtta ütlusega kuidas elu, nõnda surm, kusjuures alles surm toob nähtavale elu tõelise palge. At the end of his life, seisab artiklis, he was still investigating, still questioning. It's said that his last words were "What's this?" (Oma elu lõpus uuris ta ikka veel, esitas küsimusi. Kuuldavasti olid tema viimased sõnad "Mis see on?"; Newsweek 1990, 29. oktoober: 80) - mittemidagiütlevad, triviaalsed viimsed sõnad, võiks nentida, kuid siiski annavad need põhjuse (viimsete sõnade kultuuri ajaloos üldlevinud ${ }^{21}$ ) katseks kuulda neis kõlavat mingit sügavamat tähendust, kartuses, et lõhutud, ringiks tõmbamata elukaar pole piisavalt väärikas. Postmodernsena kohtab seda katset Newsweeki (1990, 12. veebruar: 88) järelehüüdes Guami endisele kubernerile Ricardo J. Bordallole, kes osundavalt vihjas ühtedele tuntuimatest viimsetest sõnadest, harjutades oma demonstratiivselt avalikku enesetappu ad hoc valmistatud plakati ees kirjaga: I regret that I only have one life to give to my island ( $M a \mathrm{ka}$ hetsen, et mul on ainult üks elu, mida ohverdada oma isamaa eest).

Järelehüüdest on vaid üks samm biograafiani. Enne siiski veel mõningatest ajalehtede ja ajakirjade nn kohustuslikest (sine qua non) rubriikidest, mida oleks viimsete sõnadeta suisa raske ette kujutada. Riikides, kus endiselt (või uuesti) rakendatakse surmanuhtlust, kuuluvad teated surmamõistetute viimsetest sõnadest hukkamisel (elektritoolil, enne poomist, mahalaskmist või letaalset süsti) peaaegu iganädalaste teemade hulka ning ka teiste maade ajakirjandus ei lase käest võimalusest seda teemat käsitleda. Nii näiteks ilmus populaarses ajakirjas Focus sensatsioonimaiguline artikkel "Letzte Worte vor der Hinrichtung" ("Hukkamiseelsed viimsed sõnad"), mis sisaldas harilikult jubedust tekitavaid (mitte ainult verbaalseid) detaile (Focus 1994, 8. august: 156). Hukkamisrituaaliga kaasnev moodustab viimsete sõnade kultuuris omaette subkultuuri, millel on kogu Euroopas pikk ja hästi dokumenteeritud ajalugu, seda eriti nende sajandite osas, mil hukkamised olid hoopis avalikumad kui televisiooniajastul (vrd Guthke 1992: märksõna executions; uusimaid selleteemalisi raamatuid Gatrell 1996). 


\section{Karl Siegfried Guthke}

Hästi on seda kujutatud Patrick Süskindi (1985) menuromaanis Parfüüm (Das Parfum). Nagu Inglismaal oli kombeks kuninganna Elizabeth I ajal, nii on Ameerikas ilmselgelt ka tänapäeval tavaks (ja see pole filmitööstuse leiutis) küsida süüdimõistetutelt, kas neil on oma viimsel eluhetkel veel midagi lausuda, ja teavitada siis sellest avalikkust. ${ }^{22}$ Ka vastused, mida võib leida 1990. aastate ajakirjandusest, kõlavad tihti kui kaja kaugest minevikust. Shakespeare'i aegadest on tuttavad juhtumid, mil surmamõistetu esitab oma elu lõppu kui teatrietüüdi. Nii oli see näiteks 1995. aastal Oklahomas röövmõrtsukas Thomas Grasso hukkamisel, mille tegid täiuslikuks paljundatud viimne teade surmanuhtluse poolt- ja vastuargumentidega ning sellele järgnenud mõistatuslikud laused, milles vanglaametnik tundis hiljem ära Thomas Stearns Elioti luuleread, sellele liidetud omaloominguline luuletus ning lõpuks (parodeeriv?) palve anda ajakirjandusele teada, et viimne eine ei vastanud surmamõistetu soovile: Please tell the media, I did not get my Spaghetti$O$ 's. I got spaghetti. I want the press to know this (Palun teavitage meediat, et ma ei saanud soovitud Spaghetti-O'sid. Mulle anti lihtsalt spagette. Tahan, et ajakirjandus teaks seda). Ja tema tahtmine sündis (New York Times 1995, 21. märts: B6). Kristlikud hukkamiskonventsioonid on säilitanud oma mõjujõu veel 1990. aastatel, kui tapjad, Jeesus Kristuse nimi huulil (New York Times 1993, 6. jaanuar: A10; 1998, 4. veebruar: A20), paludes andestust ${ }^{23}$ (New York Times 1996, 20. juuli 1. osa: 7; 1996, 23. august: A15) või vankumatu lootusega kohtuda "taevas" taas oma - nagu tänapäeval öeldakse - sotsiaalse keskkonnaga (New York Times 1995, 23. märts: A21) surmale vastu astuvad. Teised jälle kinnitavad oma süütust (New York Times 1996, 8. august: A23; 1997, 26. märts: A20) - ka see on ajaloost tuttav, kui mõelda kas või usulistele teisitimõtlejatele. Sellega võib liituda süüdistus õigussüsteemi pihta: I have news for all of you. There is not going to be an execution. This is premeditated murder by the State of Texas (Mul on teade teile kõigile. See, mis toimub, pole hukkamine. See on Texase osariigi poolt ettekavandatud mõrv; Newsweek 1995, 16. jaanuar: 15). Juhuti esineb teateid hukkamistest, kus viimseteks sõnadeks on mõni nali (nagu see oli sage Prantsuse revolutsiooni päevil), luuletus (nagu Jaapani traditsioonis) või lihtsalt teatud ringkondades levinud tervitusvormel Peace (Teeme rahu) (Harvard Crimson 1995, 20. aprill: 5; New York Times 1997, 10. jaanuar: A1; 1995, 27. juuli: A16; vrd ka New York Times 1993, 15. aprill: A16 (I love you - Ma armastan sind); 1992, 22. juu- 


\section{Karl Siegfried Guthke}

li: A13; ka Hoffmann 1986 \& 1998). Uudisekünnise ületab isegi see, kui surmamõistetul pole midagi öelda: I have no last statement (Ma ei tee mingit viimset avaldust; New York Times 1997, 27. veebruar: A21; 1997, 10. jaanuar: A21; 1995, 23. märts: A21), kuigi see ei pane tänapäeval enam külmi judinaid üle selja jooksma, nagu neil aegadel, mil oli laialt levinud uskumus, et surm hoolikalt valitud viimsete sõnadeta saadab hinge otseteed põrgusse. Lõpuks tuleb märkida, et 31. juulil 1994 avaldas New York Times (4. osa: 7) surmamõistetute viimsete sõnade süstemaatilise antoloogia - täpselt nagu neil ammustel aegadel, mil ilmus köidete kaupa poodute viimseid sõnu.

Kui hukkamine oma viimsete sõnadega tähistab kriminaalmenetluse lõppu, siis kurjategijate ohvrite viimsed sõnad mängivad päevalehtede andmeil sageli otsustavat osa eelkõige kriminaaljuurdluse algfaasis. Niisiis pole see mingil juhul kriminaalromaanide autorite leiutis. Pigem lõikavad hoopis nemad ise kasu kohtumenetlusi kajastavatest leheuudistest, nagu lõppkokkuvõttes ka tõigast, et anglosaksi õiguse järgi on kolmanda isiku vahendatud tapetu viimsed sõnad, kuigi nende asjus pole võimalik enam ristküsitlust korraldada, erinevalt igasugusest muust kuuldustest kogutud andmestikust kohtuliku tõestusmaterjalina aktsepteeritavad. Vastavalt ladinakeelsele tavaõiguse maksiimile Nemo moriturus praesumitur mentiri ${ }^{24}$ (vrd Guthke 1992: märksõna law; viimsetest sõnadest kriminaalromaanides ja leheuudistes vt Auckenthaler \& Rudnick \& Weissenberger 1997: 434-437) omistatakse neile isegi olulist kaalu, mida võib ehk pidada keskaegse pärimuse, nagu oleks surnutel tõenäitamisvõime, kaugeks järelmõjuks. Kõnealuse pärimuse kohaselt hakkavat tapetu haav uuesti veritsema, kui tapja sellele läheneb (nt Siegfriedi ja Hageni lugu). Kuidas asi ka ei ole, ikka ja jälle kinnitavad ajalehed, kuivõrd mõjukad on kohtumenetlustes ohvri viimsed sõnad, kui neis sisaldub tapja nimi. Näiteks vahistati 1995. aastal üks üürilistega tekkinud probleeme relva ja süütamistega lahendada püüdnud Connecticuti osariigi majaomanik ning mõisteti süüdi pärast seda, kui leidis kohtulikku kinnitust, et üks tema ohvritest oli oma viimsete hingetõmmete ajal nimetanud mõrvari nime (New York Times 1995, 28. aprill: B6; vrd ka Boston Globe 1989, 3. detsember, 1. osa: 12; New York Times 1990, 16. september, 1. osa: 43; 1995, 28. jaanuar, 1. osa: 22). Ühe värskema Pennsylvanias aset leidnud juhtumi puhul püüti välja selgitada, kas läbilõigatud keelega ohver oli üldse puhtfüsioloogiliselt võimeline nimetama enne surma kurjategija nime, nagu väitis tema ema (Michelle 
did it (Michelle ütles seda) (New York Times 1997, 27. detsember: A1, A8). Sama stsenaariumi omalaadses arenduses 1996. aastast lülitas üks New Jersey õpetaja elu viimsetel hetkedel salaja sisse kassettmagnetofoni, nii et maailma jäi temast tõendina maha hirmu täis, kuid samas sihikindlalt teavet koguda püüdev vestlus talle kallale tunginud ja talt elu võtnud kurjategijaga (New York Times 1996, 20. märts: B1, B7). Ka 1997. aastal Massachusettsis aset leidnud juhtumi puhul jõudis kodus kallaletungi ohvriks langenud ja surmavalt vigastatud naine oma hädahüüu viimasel hetkel helilindile jäädvustada (Boston Globe 1997, 8. november: B3). Kui see kõik kõneleb veel politseijaoskondade tavarutiinist, siis järgnev tõestisündinud lugu peaks ületama kriminullikirjutajate fantaasia. 1994. aasta alguses hoidis kogu maailma ajakirjandus hinge kinni Prantsuse süüteküünlatöösturite dünastia pärijanna madam Marchali Nizzas peetud mõrvaprotsessi kummalise detaili tõttu. Nimelt oli keegi (ohver või tapja?) kirjutanud kuriteopaigas keldriuksele madami verega Omar m'a tuer ${ }^{25}$ (sic!) - viimsed sõnad, mis pakkusid nii detektiividele, juristidele, käekirjaekspertidele kui isegi filoloogidele võimalust kriminalistikaalaseks teravmeelitsemiseks (Londoni Times 1994, 2. veebruar: 12). Aednik Omar mõisteti süüdi, kuid vabastati juba 1998. aastal süüdtõendite puudulikkuse tõttu vahi alt, kusjuures samal ajal ilmus François Foucart'i raamat (Foucart 1998), milles püüti,jällegi uksele tuginedes, Omari süüd usutavana esitada (vrd Le Figaro 1998, 4. september: B11).

Muude kriminaalsete surmajuhtumite juures, mida meedia ära kasutab, ei esinda kuulujutuna levitatavad viimsed sõnad õiguslikke huve, vaid pigem lisavad muudele katastroofiteadetele sensatsioonikõdi. Sellised efektid ulatuvad südantliigutavalt religioossetest jahmatavalt banaalseteni ehk 78-aastasest usuõpetajannast, kes 12-tollise lihunikunoaga löödud 33 torkehaava kätte surres issameiet loeb (Newsweek 1987, 21. september: 37), sunnitöövanglas mõrvatud massimõrtsuka Jeffrey Dahmeri viimsete sõnadeni Go ahead and kill me (Lase käia ja tapa mind; National Enquirer 1994, 13. detsember: 36). Neid ületab aga maksupettuste tõttu põgenenud Nevada endise prokuröri enesetapp, kes enne, kui ta endale kasiinohotellis suhu tulistas, lausus I can't do 10 years (Ma ei pea kümmet aastat vastu) (New York Times 1996, 27. november: B1). Igal juhul nähtub sellest valikust, kui laialt on viimsete sõnade skaala tänapäeva igapäevases meedias esindatud - nimelt niisama rikkalikult 


\section{Karl Siegfried Guthke}

nagu ilukirjanduses ja ars moriendi õitseajal, mis oleks esimeses näites palvetanud vanaprouale kindlustanud pääsu taevasse, kahele järgnevale aga põrguleegid. Kas see on tänapäevane erinevate aegade sünkroonsuse avaldumine?

Ka pressiteated kõikvõimalike katastroofide kohta saavad üksnes harva läbi kellegi südant liigutavate viimsete sõnadeta (vt ka Guthke 1992: 12). NASA kosmosesüstiku Challenger allakukkumine 1986. aastal tõi kaasa ülemaailmse tähelepanu: meeskonna rasvases kirjas trükitud "viimsed sõnad" vaatasid kaubanduskeskuste vitriinidest lugejatele vastu Weekly World News'i 1991. aasta 5. veebruari numbri esiküljel. Ja kui lasti vabaks Põhja-Korea kohal alla kukkunud Ameerika helikopteri piloot Bobby Hall, tõid kõik Ühendriikide üleriigilised ajalehed ära tema hukkunud kaaslenduri viimsed sõnad Bobby, I've been hit (Bobby, ma sain pihta) (New York Times 1995, 1. jaanuar, 1. osa: 25), vaatamata nende ületamatule triviaalsusele. Niisamuti ei saa viimsete sõnadeta hakkama uudised väiksemat rahvusvahelist või sisemaist huvi äratavatest õnnetustest, isegi kui nende eesmärk lugejatele pisarad silma tuua on piinlikkust tekitavalt läbinähtav. Daddy, I love you - need olid mitte ainult selle 14-aastase Louisiana tüdruku viimsed sõnad, kes nalja pärast õhtul koju saabunud isa ehmatas, mispeale isa teda välkkiirelt püstolist tulistas, vaid ka selle 20-aastase tütre omad, kes sai tabamuse Iirimaal hingedepäeva jumalateenistusel IRA korraldatud pommirünnakus (New York Times 1994, 9. november: A18; TV Quick 1992, 7.-13. november: 27).

Hakkab juba tekkima tunne, et ajakirjanikel on selliste juhtumite puhuks igasse olukorda sobivad viimsed sõnad varnast võtta, kuid nagu kaks järgnevat näidet tõestavad, on see kahtlus siiski alusetu. 15-aastane Florida poiss keeldus võtmast ravimit, mis oleks talle siiratud maksa äratõukereaktsiooni neutraliseerinud, ja suri pärast seda, kui oli palunud emal end käte vahele võtta (New York Times 1994, 22. august: A14). Ja süngemast süngem episood: lugu Rhode Islandis elanud siiami kaksikutest, kellest üks teise surres, teades, et temalgi on pärast õe lahkumist jäänud elada vaid mõned minutid, jagas viimsete hingetõmmete ajal korraldusi, kellele tuleb nende nimel lilli saata ja kuidas neid tuleb matta (krematsioon), kusjuures reporter ei ole suutnud jätta lisamata, et õed olid laulnud kirikukooris ja nende lemmikspordialaks oli olnud rattasõit spetsiaalselt nende tarbeks valmistatud kahe sadulaga kolmerattalisel (New York Times 1991, 22. juuli: A10). 
Karl Siegfried Guthke

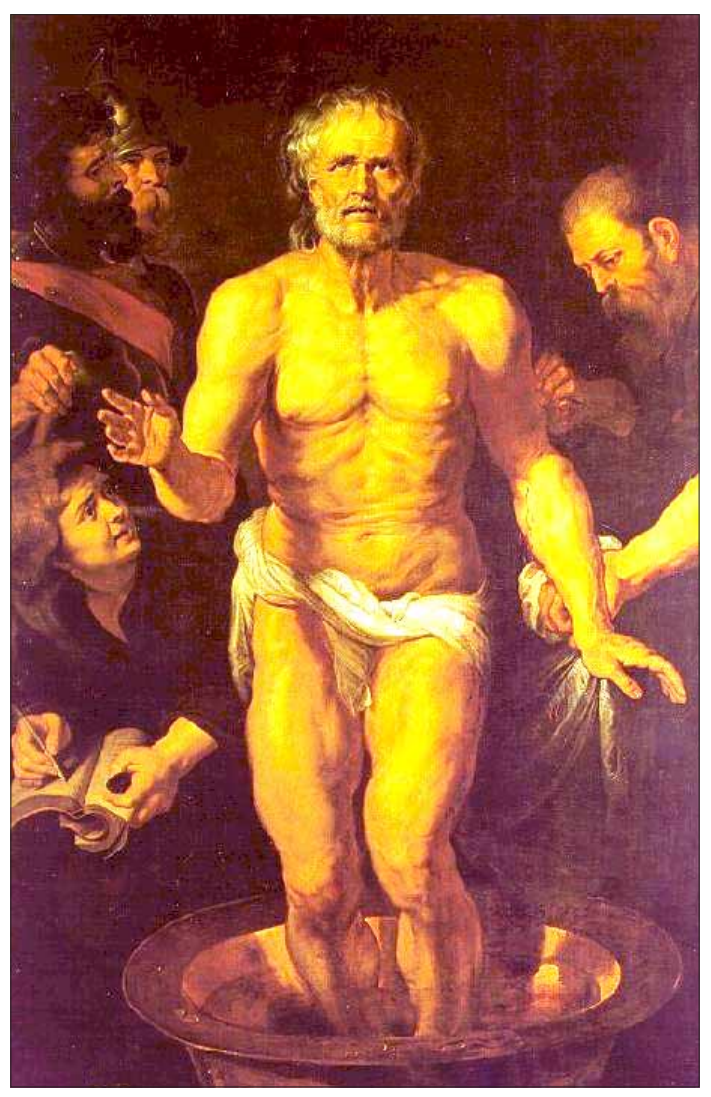

Foto 2. Rubens (1577-1640). Surev Seneca (1615; ôli, lõuend). Repro.

Sellised juhtumid paiknevad juba üleminekupiiril teise ajakirjanduse samavõrd olulisse kategooriasse, milleks on human interest [feature] story (üldhuvitav [olemus]lugu). Tegemist on teadetega viimsetest sõnadest, mis äratavad tähelepanu pelgalt oma erakordsusega ja on eriti armastatud ingliskeelses maailmas, kus ekstsentrilisus on elustiilina jätkuvalt hinnatum kui kusagil mujal. Kes muu, kui mitte inglane (praegusel juhul Sacheverell Sitwell) peaks märkimis- ja avaldamisväärseks, et on valmistatud Havanna sigareid nimega Dernier Mot Nr $2^{26}$ (Sitwell 1953: 75)? Kes teine, kui mitte Ameerika ajakirjanik (nimelt seniajani kõrgelt hinnatud Janet Flanner) edastaks 1920.-1930. aastate Pariisist, millised olid tant- 


\section{Karl Siegfried Guthke}

sijanna Isadora Duncani viimsed sõnad (autoõnnetusel öeldud: Je vais à la gloire (Ma saan kuulsaks)), millised Rumeenia krahvinna de Noailles'i (I have so loved France and the Frensch (Ma armastasin väga Prantsusmaad ja prantsuse keelt)), millised Mata Hari (Vive l'Allemagne (Elagu Saksamaa)) või hoopis Prantsuse Vabariigi presidendi Paul Doumer' omad, kes oma elu viimsetel hetkedel juurdles selle üle, kuidas saadi saata takso Maison Rotschildis korraldatud heategevuspeole (Flanner 1988: 35, 83, 93, 124)?

Maade puhul, mille ajalehed selgitavad aasta lõpul välja mitte ainult parima filmi ja raamatu, vaid, nagu seda 1996. aastal tegi Denver Post, ka parimad viimsed sõnad, ei pane imestama, et kõikvõimalikud viimse sõna kurioosumid on ühiskonnas nähtaval kohal, isegi ja eriti siis, kui nende laiem üleilmne kandepind piirdubki vaid human interestiga. Sugugi mitte juhuslikult kuulub nende hulka teade Loch Nessi koletisest, kes kahtlemata hoiab enda käes sensatsioonide pikaealisuse rekordit. 1994. aastal selgus, et esmakordselt 1934. aasta Daily Mailis ilmunud ja sestsaadik korduvalt avaldatud koletise foto on võltsing (tegelikult kujutab see mänguallveelaeva), sest pildi autor tunnistas surivoodil pettuse üles (People 1994, 28. märts: 109). Nii sai selle loomalembuse eriliigi aeg ümber. Et aga loomaarmastusega seotud viimsed sõnad (tuntud on näiteks Friedrich Suure viimsed sõnad oma hurtadele) võimaldavad ikka veel tunnetel mängida, tõestab järgmine tähelepanuväärne kuulujutt, mis leidis pikemat kajastamist isegi New York Timesis (1998, 14. november: A14). Nimelt otsiti Connecticuti osariigis Norwalkis nädal aega 10000 plakati, 40000 postiteatise ja tosinate abistajate jõul lühikese karvaga pruunilaigulist hirvesilmadega inglise linnukoera, kusjuures leidjale oli välja pandud 10000 dollari suurune vaevatasu. Miks? Koeraomaniku viimsed sõnad olid olnud Please find my dog (Palun otsige mu koer üles) ning tema kasuisa tegi kõik, mis tema võimuses, et seda viimset soovi täita - väga anglosaksipärane näide testamendilaadsete inimese viimsete sõnade kõikvõimsa jõu kohta, millest rääkis Botho Strauß (1981: 55) oma teoses Paare, Passanten (Paarid, möödujad).

Ajakirjanduses palavalt armastatud kurioosumite hulka kuuluvad ka teated lauljaid ja näitlejaid laval ootamatult tabanud surmast (selles vallas on tuntuim eelkäija Molière). Võrratuks näiteks selle kohta on Boston Globe'is (1996, 6. jaanuar, 1. osa: 3), aga ka teistes väljaannetes kajastamist leidnud lugu ooperilaulja Richard Versalle' südameatakist Leos Janáceki igavese nooruse teemalise 
ooperi Makropulose juhtum (The Makropulos Case) etenduse ajal New Yorgi Metropolitani ooperimajas. Surm tabas lauljat vahetult pärast sõnade You can only live so long ( $S$ a võid elada üksnes nii kaua) ettekandmist. 1994. aastal käis ajalehtedest läbi ja jõudis isegi National Public Radiosse (uudised 10. aprillil kl 18; Boston Globe, 13. aprill, 2. osa: 20) järgmine, pigem naljakas lugu: Massachusettsi osariigi Newtoni linna populaarne meer Ted Mann, parodeeris surivoodil aastasadu vana ja väärikat pattude ülestunnistamise traditsiooni, ütles poja andmeil viimase asjana: I buried Jimmy Hoffa (Mina matsin Jimmy Hoffa) - rekkajuhtide aastaid tagasi segastel asjaoludel jäljetult kadunud ülemuse.

Sama traditsioonilised kui järelehüüded ja pattude ülestunnistamised viimsel hetkel on patriootilised hüüdlaused (vrd Guthke 1992: 5, 14, 15; ka Mata Hari eelosundatud Vive l'Allemagne ja AlainFournier Vive la France! (Elagu Prantsusmaa!). Adolf Eichmanni juba nimetatud multinatsionaalsele hüüatusele võib vastukaaluks tuua Auschwitzis poodud Poola patrioodi lahkumissõnad Lang lebe Polen! (Elagu Poola!; Newsweek 1995, 16. jaanuar: lk 53) või Klaus von Stauffenbergi (mitmes variandis levinud) lang lebe [unser geheimes? unser heiliges?] Deutschland! (elagu meie [kodune? meie püha?] Saksamaa! (veel 1994. aasta 5. augusti Times Literary Supplementis arutleti nende üle seoses Michael Baigent'i ja Richard Leigh'i teosega Secret Germany (Saladuslik Saksamaa)) ning Joachim von Ribbentropi nendega peaaegu identsed viimsed sõnad (viimati 6. juunil $1998 \mathrm{kl} 21$ telekanalil BBC 2 dokumentaalfilmisarjas Reputations). Adolf Hitleri viimsete (antisemiitlikku "patriotismi" illustreerivate) sõnade vastuolulise tähendusega tegeles ajakirjandus veel 1995. aastal (New Yorker 1995, 1. mai: 58), millele moodustab meeldiva kontrasti Hildegard Hamm-Brücheri mälestustest pärinev õdevenda Schollide hüüatus tapalaval: Es lebe die Freiheit! (Elagu vabadus!) (Zeit-Magazin 1999, 11. märts: 10). Viimsete sõnade järele puudus aga igasugune vajadus, kui 1994. aastal lahkus 88-aastasena juba tummfilmides kuulsust kogunud Gilbert Roland, sest tema oli oma mehhiklannast ema viimseid sõnu Mein Sohn, haste nicht, mach dir keine Sorgen, lebwohl, meine Seele (Mu poeg, ära kiirusta, ära muretse, ela hästi, mu hing) kandnud juba aastaid kuldsõrmusele graveerituna vasaku käe väikeses sõrmes. Kummalisest vormist hoolimata on see muljetavaldav meeldetuletus viimsete sõnade rollist argikultuuris, sõnade rollist, mis on justkui väärtuslikud perekonna-aarded, mida antakse edasi põlvest põlve eesmärgiga neis 


\section{Karl Siegfried Guthke}

peituvat elutarkust kuulda võtta (New York Times 1994, 18. mai: B8). Seda laadi loos on pereajakirjadele ja pühapäevalisadele omane inimlik huvi käegakatsutav, nagu ka Boston Globe'i nädalalõpulisas Magazine (1995, 19. veebruar: 10) ilmunud ajakirjanik Daniel Goldeni jutus tema isa näitlikult heast suremisest (he died well), mis taas kord kinnitab vana vormelit kuidas elu, nõnda surm: eeskujulik nagu selle perekonnaisa elu (hobid: Mozart, filmikoomikutest vennad Marxid ja pesapall), oli ka tema surm ning tema viimseteks sõnadeks oli elupõlisele abikaasale esitatud küsimus: Are you OK? (Kas sinuga on kõik korras?).

Seda tõestisündinud lugu ei pakuta hea suremise musternäidisena sugugi umbropsu. Meie ajal, kui asjakirjanduses ei tõsteta suurte, üle mitme veeru jooksvate pealkirjadega esile üksnes hospitsiliikumise ${ }^{27}$ ja aeglase AIDSi hääbumise teemat, vaid ka kirjutisi võitlusest eutanaasia seadustamise eest - mis poleks mõeldavgi ilma eluga hüvasti jätvate viimsete sõnade erilise rõhutamiseta - , tungib viimsete sõnade kultuur lõpuks ka populaarsetesse pere-, naiste- ja nädalalõpuajakirjadesse. Ja seda mitte ainult õudust ja kaastunnet tekitavate artiklite kujul viimsete sõnade fenomenist kultuuris, mida ülearu selgelt ei eelista isegi Wystan Hugh Auden (Harper's Bazaar 1941, oktoober: 83, 119; ka Zeit-Magazin 1999, 6 mai: 6), vaid palju enam püüdena arutleda süvitsi oskuse üle hästi surra. Nii ilmuski Newsweeki 1996. aasta 25. novembri numbris kirjutis "The Art of Dying Well" ("Hästi suremise kunst"), mis juba pealkirja kaudu otsib ühendust hilisesse keskaega tagasiulatuva traditsiooniga tähtsustada lõpurepliike selles draamas - ja mõnikord ka näitemängus - , mida inimelu endast kujutab. Paljuski keerleb nimetatud artikkel kardinal Joseph Bernardini surma ja viimsete sõnade ümber, kuid peatutakse ka budistlikel, islami ja juudi õpetustel viimse eluhetke tähendusest, rääkimata Jacques Louis Davidi maalist Sokratese surm, mis kujutab efektselt kreeka targa lennukaid viimseid sõnu.

III.

Kas viimsed sõnad on leidnud koha ka kujutavas kunstis? Pöördudes nüüd trükiajakirjanduse ja vaid riivamisi käsitletud televisiooni ja raadio juurest teiste meedialiikide poole, tuleb sellele küsimusele anda kõigiti jaatav vastus. Juba ajaloolise ars moriendi juurde kuu- 
Karl Siegfried Guthke

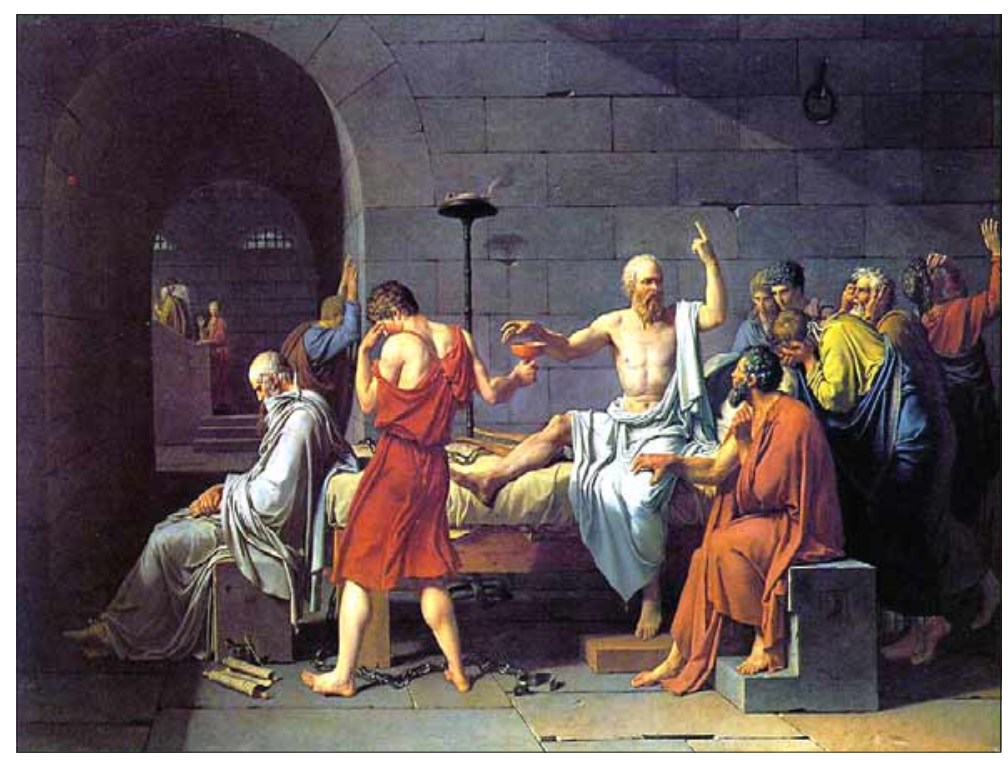

Foto 3. Jacques Louis David (1748-1825). Socratese surm (1787; õli, lõuend). Repro.

lusid illustratsioonid, kus viimseid sõnu tavatseti kujutada surija suust väljuva loosungina. Hiljem, alates renessansist, kuulusid suremisstseenid maalikunsti raudvarasse, eriti veel nende filosoofide suremisstseenid, kelle viimsed sõnad olid hästi tuntud (Sokrates, Seneca, Cato). Jacques Louis Davidi Sokratese surm jätab varju nii Rubensi Sureva Seneca kui ka vähetuntud Fritz Fleischeri maali Rohkem valgust, millel on kujutatud rohelisse biidermeieri tugitooli vajunud surevat Johann Wolfgang von Goethet spartalikus magamistoas. Kõigil neil piltidel kohtab avatud suid ja ülestõstetud käsi kui šifreid, mis juhivad tähelepanu tuntuks saanud viimsete sõnade väljaütlemise hetkele (vrd Guthke 1992: 28-29, 61, 82; Olds 1966; OberreuterKronabel 1986). Oma kuulsa õlimaaliga Marat' surm katsetas J. L. David ka teist strateegiat ning püüdis teha võimatut võimalikuks, sõna maalitavaks: surnul on veel käes hanesulg, millega ta just lõpetas kõrval puukastil lebava kirja kirjutamise; maal oli Times Literary Supplementi 1995. aasta 6. oktoobri numbri kaanepildiks.

Niipalju siis üldistest, teoreetilistest probleemidest seoses viimsete sõnade edasiandmisega visuaalsetes meediates. Meie kaasajale 


\title{
Karl Siegfried Guthke
}

hoiti aga varuks võimalus pühendada viimsetele sõnadele terve kunstinäitus ja sellega nende tähendus kultuuriinstitutsioonina sõna otseses mõttes nähtavaks muuta. Jutt käib Christina de Vosi kuuest maalist ja tosinast tušijoonistusest viimsete sõnade teemal, mis olid väljas 1997. aasta sügisel Haagis Ronkes Agerbeeki galeriis. Läbivalt enam-vähem ühesuguse lahendusega teostatud, kujutas iga töö mingit ajaloolist või kirjanduslikku tegelast (näiteks Orson Wellesi 1941. aastal valminud samanimelise debüütfilmi (originaalpealkirjaga Citizen Kane) peategelane kodanik Kane, Dutch Schultz (Arthur Flegenheimer), Anna Pavlova, Gladstone, Elizabeth I, Johann Wolfgang von Goethe, Prints Albert, Katherine Mansfield jt), kelle kehale olid kunstipärase leidlikkusega kirjutatud temale omistatud ning antoloogiatesse või haritlaste folkloori jõudnud viimsed sõnad - niisiis originaalne ja õnnestunud ettevõtmine, mis nõuab jätku.

Et kirjandus viimsete sõnade institutsioonist kasu lõikab, on enesestmõistetav ega vaja siinkohal pikemat lahtiseletamist. Meediatsivilisatsiooniga seoses väärib aga siiski mainimist, et Erich Friedi luuletus "Bevor ich sterbe" ("Enne, kui suren") jõudis koguni Frankfurter Allegemeine Zeitungi Marcel Reich-Ranicki koostatud Frankfurdi antoloogiasse:

\author{
Noch einmal sprechen \\ von der Wärme des Lebens \\ damit doch einige wissen: \\ Es ist nict warm \\ aber es könnte warm sein \\ Bevor ich sterbe \\ noch einmal sprechen \\ von Liebe \\ damit doch einige sagen: \\ Das gab es \\ das muß es geben
}

Noch einmal sprechen vom Glück der Hoffnung auf Glück damit noch einige fragen:

Was war das

wann kommt es wieder? ${ }^{28}$ (Reich-Ranicki 1986: 213.) 
See on üks ilmselgeid vihjeid viimsete sõnade kultuurile selle tänapäevasel kujul. Pigem küünilises valguses esineb see kultuur Frank Conroy menuromaanis Body and Soul (Ihu ja hing; Boston 1993):
“Ta oli just midagi ütlemas.”
"Surivoodil räägitakse romaanides. Sopran paljastab oma hinge ja variseb divanile. Kodanik Kane ja tema Roosinupp (Rosebud). Küllap me seda tahamegi. Mingit sõnumit, mingit viimsetel hetkedel väljendatud sõnumit. Millal veel peaks see kõik arusaadav olema, kui mitte lõpus? Aga see ei ole arusaa- dav." Ta avas oma silmad. "Viimsed hetked on samasugused kui mis tahes muud hetked. Nendes ei ole erilist tarkust"29 (Conroy 1993: 119).

Film, et ka seda riivamisi mainida, ei jää mõistagi oluliselt maha. Orson Wellesi Kodanik Kane ei ole ainus, mis ainult viimse sõna ümber keerlebki (kuigi Kane'i viimane sõna Rosebud on kindlasti ainus tänu filmile lendsõna staatusesse tõusnud viimne fraas, mis on ka väljaspool Ameerikat kõikidele tuttav. (Märkimist väärib, et üks osa kriminaalseriaalist Columbo (BBC 1, 19. juuli 1998, kl 14.20) peaosas kultuskangelase Peter Falkiga keerleb ümber tunnussõna Rosebud, mille kuulmise peale on üks filmirekvisiitide koguja treeninud oma dobermannid surmavalt ründama (Zeit-Magazin 1999, 28. jaanuar: 6; Thomson 1996). Saksamaal seevastu alustas ilmumist uus disainiajakiri nimega Rosebud, mille nimevalikut väljaandja Ralf Herms põhjendab Orson Wellesi võimega ammendada igas teoses täielikult kasutatava meediumi võimalused. Seega pole üllatav, et ka üks O. Wellesi biograafiatest (Thomson 1996) kannab sedasama lihtsat tiitlit Rosebud.) Saksa filmihuvilistele meenub siinkohal kindlasti Werner Herzogi linateos Letzte Worte (Viimased sõnad), kuigi režissöör on pidanud silmas pigem vabatahtlikku viimset väljendust, mõeldes ehk guru Baba Meherile, kes lausus oma viimased sõnad 1925. aastal, kuid elas pärast seda veel aastakümneid. Michael Ondaatje romaani The English Patient (Inglise patsient) ekraniseering kuulub mõistagi ühte ritta vanemate filmidega The Fugitive (Põgenik), It's a Mad, Mad, Mad, Mad World (Meeletu, meeletu maailm) ja Menace II Society.

Viimseid sõnu kohtab tänapäeva meediakultuuris igal sammul. Pole siis ime, et humoristid ja satiirikud on selle teema juba ammu üles leidnud (vrd Guthke 1992: märksõna jokes), mis torkab eriti silma New Yorkeris, aga ka üliõpilaste naljalehtedes (The Harvard 


\section{Karl Siegfried Guthke}

Lampoon CLXXXV: 3 (1995): 37) ja TV-show'des (nagu näiteks ühe punanaha viimsed sõnad Y'all watch this (Seda ma veel vaatan), mis avaldati New Yorgis Jeff Foxworthy mass market paperboundis ehk pehmes rahvaköites pealkirjaga No Shirt. No Shoes - no Problem! (Pole särki. Pole kingi - pole probleemi!) (Foxworthy 1996: 31). Seda tähelepanuväärsem on, et isegi Ernst Jüngeri kogumiskirg ei suuda sellistele lõbudele vastu panna: 25. jaanuaril 1979 kirjutas ta oma päevaraamatusse:

Vennapoeg Gert täiendas minu viimsete sõnade kogu; alati satub sel puhul ette ka midagi naljakat.

Kindral John Sedwick [ütles] lahingus Spotsylvania all mõnedele meestele, kes pü̈̈dsid hirmunult tulistamise eest varju leida:

"Edasi, edasi! Sellelt kauguselt ei saaks nad ju isegi elevandile pih..." ja kukkus surnult maha (Jünger 1981: 440441).

Anekdoodid ajalooliste isikute viimsete sõnade kohta on laialt tuntud ja ka meedias kohtab neid sageli. Marco Polo, nagu nüüd räägitakse, suri sõnadega: Pooltki sellest, mis ma näinud olen, pole ma jõudnud edasi rääkida (Geyer 1994: 158). Lisaks salapärastele kullakaevajaile ja aardeotsijaile (Mayhew \& Bulpin 1993: 257; Mackay 1963: 45) pakuvad sellistele anekdootidele rikkalikku ainest laevahukuohvrid. Seda vähemalt alates aastatel 1812-1813 peetud Inglise-Ameerika sõja kangelasest kapten James Lawrence'ist ja tema vanasõnaks muutunud viimsest lausest Don't give up the ship (Ärge andke laeva käest). Charles Frohmani viimsed sõnad Why fear death? Death is only a beautiful adventure (Miks karta surma? Surm on vaid ilus seiklus), lausutud siis, kui ta seisis 1915. aastal silmitsi Lusitania hukuga , on pääsenud John Bartletti kogumikku Familiar Quotations (Bartlett 1980: 574); Titanicu kapteni Edward J. Smithi viimsete sõnade ümber põimuvad senini, kusjuures iseäranis just tänapäeval, kõikvõimalikud erinevates variantides legendid, millest rahvasuhu on kinnistunud Be British (Jää(ge) inglas(t)eks) (Cooper 1992: 136-137). Nagu meedia meile ikka ja jälle meelde tuletab, näivad Nobeli preemia laureaadid, juhtivad pedagoogid, rahvuskangelased ja luuletajad just oma viimsete sõnadega tõusvat anekdoodikangelase ja seeläbi surematu staatusesse. ${ }^{30}$ Vahest kuulsaim juhtum seostub Austraalia rahvuskangelase Ned Kelly viimsete sõnadega enne tema hukkamist (Such is life - Selline on elu) - 
tänu Joseph Furphy (avaldatud 1903. aastal Tom Collinsi pseudonüümi all) tohutult populaarsele samanimelisele romaanile ja hiljem Austraalia tuntuima maalikunstniku Sidney Nolani Ned Kelly hukkamist kujutavale maalile muutus Such is life omamoodi lööklauseks, mis väljendas kõike n-ö austraaliapärast. (Pole ime, et sama tiitlit kannavad ka S. Nolani biograafiad (Collins 1986; Adams 1987).)

Rohkem või vähem anekdootlikud viimsed sõnad on tänapäeva meediakultuuris nii üldiseks muutunud, et isegi selles polnud enam midagi eriskummalist, kui Orlando Figes alustas 24. mail 1998 Hayon-Wye festivalil peetud ning hiljem Times Literary Supplementis trükitud kõnet "The Russia of the Mind"Venemaa intellektuaalsest identiteedist koguni kolme ajaloolise tegelase viimsete sõnadega:

Gogoli viimsed sõnad, kui ta lamas suremas ise endale paastumisega tekitatud vaevade kätte, olid: "Tooge mulle redel. Kiiresti, redel!” Justkui oleks tal teise ilma lendamise hetkel mõlkunud meeles aken, mis muudab Gogoli sõnad traagiliselt - ja samas koomiliselt - vihjeliseks kogu tema elu suhtes (mis tal võib-olla just selsamal hetkel silme eest läbi jooksis). Selles mõttes on need sarnased Goethe viimsete sõnadega "Rohkem valgust, rohkem valgust!" Ja pole kaugel ka W. C. Fieldsi läbiharjutatud fraasist, kes, kui temalt Piibli lugemise põhjust küsiti, vastas: "Ma otsin väljapääsu."

Kuid Gogoli sõnad viitavad sügavamale sisemisele võitlusele reaalsete ja transtsendentaalsete maailmade vahel (Figes 1998: 14).

See on viimsete sõnade kultuur kõige puhtamal kujul, esinedes 1998. aastal korraga nii omamoodi rahvapeol kui ka intellektuaalide nädalalehes - viimne sõna kui avaldus surija elu ja iseloomu kohta. Miski ei tõesta selle kultuuri meie mõttemaailma juurdumist selgemini, kui William Somerset Maughami vastavasisuline paroodia - nii nagu paroodia meid ju sageli enesestmõistetavaks muutunud nähtustest teadlikuks teeb. Pean silmas tuntud jutustust "Miss King"W. S. Maughami kogumikust Ashenden, or the British Agent (Ashenden ehk Briti agent). Lugu keerleb algusest lõpuni selle ümber, kas ajurabandusse suremas olev isamaa reetnud naisluuraja suudab edastada tema juurde kutsutud Ashendenile tähtsa, salajase ja kiireloomulise teate, mille väljaütlemisega ta kogu oma jõudu kokku võttes vaeva näeb. Ta suudab seda, kuid see, mida ta lõpuks kuuldavale toob, - lihtsalt sõna England (Inglis- 


\section{Karl Siegfried Guthke}

maa), isegi ilma hüüumärgita -, on oma kontekstituses täiesti mittemidagiütlev (Maugham 1941: 47; sama autori teise paroodia kohta vrd Guthke 1992: 32). Suurepärane koomika, kuid mitte ilma sügava mõtteta, mis on andnud W. S. Maughami uuematele biograafidele põhjuse lõpetada käsitlus tema elust viitega ülalnimetatud novellile ja küsimusega, kas kirjanik pole selles kujutanud ennetavalt enda surma ja seeläbi oma elu sigillum verit, vabatahtlikult ekspatrieeritu varjatud kodumaaigatsust (Calder 1989: 385386). Mõttetihedate, kokkuvõtvate viimsete sõnadeta on elu, eriti veel avaliku tähelepanu orbiidis möödunud edukas elu mõeldamatu. Isegi Karl-May-Handbuch ei säästa meid oma kangelase viimsetest sõnadest (Ueding 1987: 123). See üldtuntud ettekujutus lööb välja David Shephardi monolavastusele Keats osaks saanud hukkamõistvas arvustuses, kus heidetakse ette, et tükis isegi ei mainita John Keatsi kuulsaid viimseid sõnu - ning sellega on retsensendi arvates kõik otsustatud (New York Times, 27. august 1996: C12).

Biograafiate kui kõigist teaduslikest žanridest kõige meediasõbralikuma viljelejad on asja ammu ära tabanud, seda enam tänapäeval, mil raamatud on taas täis kuulsuste viimsete päevade ja tundide kirjeldusi, mis loomulikult tipnevad kangelase viimsete sõnadega (vastandina Briti kõmu-uudistes omaette žanriks kujunenud lugudele võidusõiduhobuste viimsetest tundidest ${ }^{31}$ ). Ainsa uuema näitena paljudest olgu nimetatud Alexander Poznansky Tschaikovsky's Last Days (Tšaikovski viimased päevad; 1996). Üheks vanimaks meistriks selliste viimsetele sõnadele toetuvate biograafiate vallas (mis piltlikult või sõna otseses mõttes algavad lõpust) võib pidada Lytton Stracheyt ja tema kuninganna Victoria elu käsitlevat Life'i. Oma maneerlikkuses eneseparoodiani küündiv tõeline selle laadi tour de force on sama autori kirjutatud 18. sajandi alguses elanud Cambridge'i professori John Colbatchi elulugu, kelle viimseteks sõnadeks oli Horatiuse tsitaat, mis väidetavalt olla mänginud J. Colbatchi elus saatuslikku rolli (Starchey 1931: 69).

Ja mida teeksid ka tänapäeva (eelkõige populaarsed) biograafiad ilma viimsete sõnadeta, mille poole nad aplombikalt või melodramaatiliselt triivivad! Jõudmata viidata väikseimalegi osale nendest, toon siinkohal vaid paar näidet. Jorge Luis Borges on sarnaselt oma biograafidega pidanud oluliseks, et tema ema - kirjaniku elus ülisuurt rolli etendanud viktoriaanlike kommetega daami - viimsed sõnad olid ühtlasi esimesed siivutu varjundiga vandesõnad, mis ta oma elu jooksul lausus, nimelt: Carajo, basta de sufrir (Woodall 
1996: 286; Rodríguez Monegal 1978: 474). Ka Volodia Teitelboim ei suuda oma "intiimses" Pablo Neruda biograafias jätta mainimata imetletud kangelase viimseid sõnu Me voy, me voy (Ma lähen, ma lähen), mis lugejale midagi ei ütle, aga võib-olla asja iva just selles peitubki (Teitelboim 1991: 506). Paul R. Cutrighti ja Michael J. Brodheadi kirjutatud teoses Elliott Coues. Naturalist and Frontier Historian (Elliott Coues. Loodusteadlane ja rindeajaloolane) on peetud kinni ütlusest kuidas elu, nõnda surm, märkides, et E. Coues olevat viimsel hetkel kogu varasemate aegade elujõuga hääles hüüdnud: Welcome! Oh, welcome, beloved death (Tere tulemast! Oo, tere tulemast, armastatud surm) (Cutright \& Brodhead 1981: 420). Jeffrey Meyers andis oma Wyndham Lewise biograafiale nimeks The Enemy (Vihamees) ja lasi kangelasel elust lahkuda pealkirjale kohaste tülinorivate sõnadega (Meyers 1980: 329). Liiga tabavat viimset sõna peab silmas Lothar Machtan, kui ta lõpetab teose Bismarcks Tod und Deutschlands Tränen (Bismarcki surm ja Saksamaa pisarad) järgmiselt: Mida ta enne seda veel öelda jõudis, selle üle on [---] palju fantaseeritud (Machtan 1998: 65). Alan John Percivale Taylor jõudis oma teoses Bismarck koguni järeldusele, et Otto von Bismarcki oletatavasti viimne sõna Vorwärts! (Edasi!) olevat olnud isegi tema ettevalmistatud kõnedest parem (Taylor 1974: 207). Populaarsete biograafiate žanris on aga uuemal ajal siiski ületamatu Hugo Vickersi raamat Bloomsbury tippfotograafist Cecil Beatonist. Kuna C. Beatoni viimsed välja öeldud sõnad ei andnud just palju (kuid on siiski truult ära toodud: Funny sending for you - doctor - in the middle of the night! (Imelik on teid, doktor, keset ööd kohale kutsu$d a)$ ), lõpetab meediakogemusega ajaloolane oma teose fotograafi viimase sissekandega 58 aastat peetud päevikusse. Sissekanne lõpeb teatega kass Timmy surmast: Mina olen veel elus, kuid Timmy on siirdunud teadmatusse. Võib-olla oli tal õnne? Kes teab? (Vickers 1985: 582-583). Kummastav on, et kuna pole võimalik interpreteerida kassi viimseid sõnu, püütakse häda sunnil interpreteerida tema viimast žesti (Timmy kõhkles vaid hetke). Omal moel parodeerib see ehk tõsiseid biograafe, kes suruvad inimelu viimsete sõnade pähklikoorde, unustades seejuures mõnikord erinevalt H. Vickersist lisamast juurde sõna võib-olla, mis tähistaks ühtaegu nii nende jultumuse hüpoteetilisust kui ka kunstilisust.

Neid biograafiatest, kuid ka viimsetest sõnadest meediakultuuris üldiselt tehtud tähelepanekuid sobib lõpetama Ludwig Wittgensteini silmatorkav ja kõmuline juhtum. Kui ta 1951. aastal oma ar- 


\section{Karl Siegfried Guthke}

mastatud Cambridge'is suri, siutsusid varblased katustel, ta lausus siis oma paljukommenteeritud sõnad: Tell them I've had a wonderful life! (Ütle neile, et mul oli imeline elu!) Norman Malcolm pidas oma sõbrast ja õpetajast kirjutatud mälestuste esitrükis (Malcom 1958) seda lauset küll müstiliseks ja eriliselt liigutavaks, kuid siiski kohatuks lõpetama elu, mis oli olnud fiercely unhappy (metsikult õnne$t u$ ). Raamatu 1984. aasta uustrükile arvas selleks ajaks 73-aastaseks saanud N. Malcolm aga siiski vajalikuks lisada, et vahepeal on ta oma arvamust muutnud: kuigi Ludwig Wittgensteini elus oli palju kannatusi ja valu, sai ta tunda ka rõõmu ja palju sellest oli 'imeline' (Malcom 1984: 81, 84).

Viimsed sõnad: Oleme astunud kummalisele maale, mis tundub meile võõras, ainult avastamaks, et oleme kõik, ikka veel ja just praegu, üksnes sellele maale sündinud. Võib-olla tasub sellest tõesti, kui kasutada Guide Michelini sõnu, ringiga mööda minna.

Tõlkinud Elo-Hanna Seljamaa

Tõlgitud väljaandest: Guthke, Karl Siegfried 1999. Letzte Worte in der Medien-Kultur. Zeitschrift für Volkskunde 95: II, lk 197-219.

\section{Kommentaarid}

${ }^{1}$ Vt nt Goethe 1972 (eesti k); 1986 (saksa k) - toim.

${ }^{2}$ Vrd ka teise värssdraamaga Der Tor und der Tod (Sõge ja surm) (Hofmannstahl 1982: 78-79).

${ }^{3}$ Vrd Guthke 1992: märksõnade register (antiquity, Bible, Puritans, sagas, Icelandic); ka Beda teade Caedmoni viimsete sõnade kohta tema Historia Ecclesiastica's (1982: 400-403); Jalland 1996: 33-37; Houlbooke 1998: 6.-7. ptk).

${ }^{4}$ Vrd Karl S. Guthke (1992: 1. ptk). Selles uurimuses toetun pärast osundatud teose Last Words (Guthke 1992) ilmumist kogunenud ainesele. Iga seda laadi materjalikogu on juhuslik, ent võib, kui seda liiga kaua kasutada, pretendeerida paradoksaalsel viisil ka esinduslikkusele. Kogumistöös kaasaaitajaid on olnud palju, kuid erilist esiletõstmist väärib minu assistendi Doris Sperberi osalus.

${ }^{5}$ Rohkem valgust angloameerika [pop]kultuuris.

${ }^{6}$ Eesti k: Kui veel elus oleks see, / kes valgusesse ammu jäi, / ta surivoodil ütleks veel / vaid väsinuna: "Enam ei."

wwww.folkLore.ee/tagused 36 


\section{Karl Siegfried Guthke}

${ }^{7}$ Eesti k: Nägu seina poole / lebab Goethe surivoodil / Kuulda on vaid sõrmeküünte kriipimist / salajase ukselingi otsinguil / sellesse tulevikku / mis on pimedam // justkui oleksin ma juures viibinud.

${ }^{8}$ Eesti k: Siin me püksisittuja, / ühte teemat leierdab. / Näiteks klassikatsitaat: / "Rohkem valgust," teame me, / ütles Goethe surma eel, ta ei öelnud: "Sinna kah!"

${ }^{9} \mathrm{Nt}$ Elwyn Brooks White'i tuntud romaani Charlotte koob võrku (Charlotte's Web) lõpp: We are born, we live a little while, we die (eesti k: Sünnime, elame vähe aega, sureme (vt White 1979:112); vrd Meg Wolitzeri retsensioon (New York Times Book Review 1993, 16. mai: 23.

${ }^{10}$ Eesti keelde on seda tõlgitud kahte moodi: Jube! Jube! (Conrad 1963: 111) ja Õudus! Õudus! (Conrad 2002:162) (toim).

11 Esmatrükk Conrad 1902; Eesti raamatukogudes ingliskeelsena nt Conrad 1993, kättesaadav ka e-raamatuna (http://www.sparknotes.com/lit/ heart/), eesti keeles Conrad 1963; 2002 (toim).

${ }^{12}$ Vt Garland 2002. Romaani põhjal vändatud menufilm (režissöör Danny Boyle) kannab eesti keeles pealkirja Paradiisirand.

${ }^{13}$ Eesti k: oma viimase teona ta õpetab surema / Standersit järgides aplausi ja hõiskega!

${ }^{14}$ Schwilk 1988: 232 on ühe E. Jüngeri kartoteegisedeli; vrd ka Jünger 1977: 10. jaanuar, 1987: 28. juuni; 1990: 22. jaanuar (Jünger 1980 jj).

15 William IV suri 20. juunil 1837, pomisedes: "The Church, the Church" [kirik, kirik] - täheldus, millel pole vähematki sidet tema ülejäänud eluga (Fraser 1975: 295).

${ }^{16}$ Ajakirjas The London Review of Books (1995, 3. september: 5) reklaamitakse teost Oxford Dictionary of Literary Quotations tunnuslausega Last Words (Viimsed sõnad).

17 Üks vastupidine näide Pancho Villa juhtumi kohta, mis samas eelväidetut kinnitab: John Glatti teose The Fast Times and Short Life of River Phoenix (River Phoenixi pöörane aeg ja lühike elu) käsitlus New York Times Book Review's (1995, 16. aprill: 16) algab järgmiselt: Juhul, kui River Phoenixi viimsed sõnad 1993. aastal, mil ta lamas suremas ühe Los Angeles'i klubi ees, tõesti olid "No paparazzi. I want anonymity" (Ei mingeid paparazzosid. Tahan anonüümsust), nagu väidab John Glatt kirjutises "Lost in Hollywood" ("Hukkunud Hollywoodis"), ütleb see mõndagi selle kohta, kes ta oli.

${ }^{18}$ Originaaltekst: He would also muse about the perfect death. It would occur just after a lecture, when he had just finished presenting a proof and a cantankerous member of the audience would have raised a hand to ask, "What about 


\section{Karl Siegfried Guthke}

the general case?" It response, Dr. Eros used to say, he would reply, "I think I'll leave that to the next generation," and fall over dead.

Dr. Erdos did not quite achieve his vision of the perfect death, Dr. Graham said, but he came close.

"He died with his boots on, in hand-to-hand combat with one more problem,"Dr. Graham said. "It was the way he wanted to go."

19 Originaaltekst: for posible broadcast on the Internet.

${ }^{20}$ What's on TV? 1.-7. aug 1998, lk 58; Black Box inglise telekanalis Channel 4 12. augustil $1998 \mathrm{kl} 21$ (raamatuna Blax Box, London: Harper Collins 1999); eutanaasia dr Kevorkiani ühele patsiendile: "60 Minutes" telekanalil CBS 22. novembril 1998 (vt selle kohta The New Republic 1998, 14. detsember: 6).

${ }^{21}$ Brian O'Kill on sellest fenomenist kirjutanud terve raamatu (vt O’Kill 1986).

${ }^{22}$ Vrd New York Times 1995, 23. märts: A21: A total of 270 people have now been put o death by the states since the Supreme Court's 1976 ruling, and the routine outside the prisons has become all but unvarying: Officials emerge to tick off the detail matter-of-faculty - the condemned's last meal, his last words - and protesters pack up their candles and begin planning their next vigil (Ühendriikides on pärast Ülemkohtu vastavat otsust 1976. aastal hukatud ühtekokku 270 inimest ning välja on kujunenud omamoodi rutiin: ametnikud tõmbavad protseduuri iga läbitud etapi juurde asjalikult ristikese sü̈̈dimõistetu viimne eine, tema viimsed sõnad - , protestijad pakivad oma küünlad kokku ja hakkavad kavandama järgmist valvekorda). Raamatute kohta süüdimõistetute viimsetest sõnadest vt Guthke 1992: 22.

${ }^{23}$ Vrd I'm sorry (Anna andeks; New York Times 1996, 7. september, 1. osa: 11); apologized (vabandust; New York Times 1996, 18. juuli: A18).

${ }^{24}$ Eesti k: Surija ei valeta. Nigel Barley (1995: 57) teatel püsis uskumus surija poolt avaldatavasse tõesse veel 19. sajandilgi.

${ }^{25}$ Eesti k: Omar tappis mu.

${ }^{26}$ Prantsuse k: dernier cri - 'viimane mood' või 'viimane sõna'; bon mot 'teravmeelne ja tabav märkus'.

${ }^{27}$ Hospits - surijate õendusabi (toim).

${ }^{28}$ Eesti k: veel korra rääkida / elu soojusest / et mõnigi teaks: / See ei olegi soe / aga võiks soe olla // Enne kui suren / veel korra rääkida / armastusest / et mõnigi ütleks: / Seda oli / seda peab olema // Veel korra rääkida / õnnelootuse õnnest / et mõnigi küsiks: / Mis see oli / millal saabub see jälle?

${ }^{29}$ Originaal: "He was right in the middle of saying something."

"Deathbed speeches in novels. The soprano bares her soul and collapses on the divan. Citizen Kane and his Rosebud. That's what we want, I guess. Some 


\section{Karl Siegfried Guthke}

message, some meaning expressed in the last moments. What better time for it all to make sense than at the end? But is doesn't make sense." He opened his eyes. "The last moments are the same as any other moments. There is no special wisdom."

${ }^{30}$ Nobeli (siiski "alternatiivse") preemia laureaadi, pigemini Patagoonia natsiminevikuga, ent silmapaistva loodusteadlase kohta vt Sepúveda 1996: 155, pedagoogi kohta Scott-Giles 1975: 53; U. S. News and World Report 1991: 69: Massachusettsi Tehnoloogiainstituudi (Massachusetts Institute of Technology) juhatajat William Barton Rogersit tabas 1882. aastal keset lõpuaktusel peetud kõnet rabandus; tema poolelt lauselt katkenud teksti viimseteks sõnadeks jäid bituminous coal (bitumenoosne kivisüsi). Ameerika revolutsioonikangelane Ethan Allen vastas manitsusele Ethan, the angels expect you (Ethan, inglid tulid sulle järele) fraasiga God damn them. Let them wait (Olgu nad neetud. Las nad ootavad) (McPhee 1990: 37; John McPee versiooni järgi ka saksa keelde tõlgitud (McPee 1993) seiklusjutt Ameerika kaubalaevastikust narkootikumide ja arvutite ajastul; täiesti teises seoses esineb ka H. Feifelil (1959: 127). Charles Dickens on öelnud oma austatud naiseõe surma puhul: Thank God she died in my arms, and the very last words she whispered were of me (Jumal tänatud, et ta suri minu käte vahel ja viimsed sõnad, mis ta sosistas, olid minust; National Geographic 1974, aprill: 459). Vrd ka Edward K. Kaplani tsitaati Michelet' sõbra Poinsot' surma kohta: Oh! Monsieur, he died calling your name (Oh! Härra, ta suri, teie nimi huulil; Kaplan 1984: 35-36). See stamp on üldtuntud.

${ }^{31}$ Näiteks "The Final Hours of Kidnapped Racehorse Shergar" (Times [London] 1992, 13. detsember: 1). Loomade omistatud väljamõeldud viimsete sõnade kohta vrd Guthke 1992: 16.

\section{Kirjandus}

Adams, Brian 1987 Sidney Nolan: Such Is Life: A Biography. London \& Melbourne: Hutchinson.

Arendt, Hannah 1996. Adolf Eichmann: Von der Banalität des Bösen. Merkur: Deutsche Zeitschrift für europäisches Denken 566 (mai), lk 412-426.

The Art of Dying Well 1996. Newsweek, 25. november, lk 61-66.

Auckenthaler, Karlheinz F. \& Rudnick, Hans H. \& Weissenberger, Klaus (koost) 1997. Ein Leben für Dichtung und Freiheit: Festschrift zum 70. Geburtstag von Joseph Peter Strelka. Stauffenburg-Festschriften 3. Tübingen: Stauffenburg Verlag. 


\section{Karl Siegfried Guthke}

Barley, Nigel 1995. Dancing on the Grave: Encounters with death. London: John Murray.

Bartlett, John (koost) 1980. Familiar quotations: A collection of passages, phrases, and proverbs traced to their sources in ancient and modern literature. Boston: Little Brown.

Beda (Venerabilis) 1982. Kirchengeschichte des englischen Volkes = Venerabilis Bedae Historia ecclesiastica gentis Anlorum / Beda der Ehrwürdige 2. Günter Sptitzbart (koost). Text zur Forschung 34: 2. Darmstadt: Wissenschaftliches Buchgeschäft.

Benjamin, Walter 1977. Gesammelte Schriften 2: [Aufsätze, Essays, Vorträge] 2. Frankfurt am Main: Suhrkamp.

Bergman, Susan 1997. A Cloud of Witnesses: Twentieth Century Martyrs. London: HarperCollins.

Bernhard, Thomas 1978. Der Stimmenimitator. Frankfut am Main: Suhrkamp.

Bernstein, F. W. (= Weigle, Fritz) 1988. Lockruf der Liebe: Gedichte. Zürich: Haffmans.

Bertram, Ernst 1934. Heinrich von Kleist. Deutsche Gestalten: Fest- und Gedenkreden. Leipzig: Insel-Verlag.

Black Box 1999. London: Harper Collins.

Boston Globe 1989, 3. detsember; 1994, 13. aprill; 1996, 6. jaanuar; 1997, 8. november.

Boston Globe Magazine 1995, 19. veebruar.

Bricard, Isabelle 1995. Dictionnaire de la mort des grands hommes. Collection "Documents". Paris: Le Cherche Midi éditeur.

Büscher, Wolfgang 1998. Drei Stunden Null: Deutsche Abenteuer. Berlin: Fest.

Calder, Robert Lorin 1989. Willie: The life of W. Somerset Maugham. London: William Heinemann Limited.

Collins, Tom 1986. Such Is Life. David Malouf (sissejuhatus). London: Chatto \& Windus.

Conrad, Josep. Heart of Darkness (http://www.sparknotes.com/lit/heart/ 18. mai 2004).

Conrad, Joseph 1902. Youth: A narrative, and two other stories. Edinburgh \& London: William Blackwood \& Sons.

Conrad, Joseph 1963. Pimeduse süda: Novell. Tõlk Leo Anvelt. Loomingu raamatukogu 26/37 (304/305). Tallinn: Ajalehtede-Ajakirjade Kirjastus. 


\section{Karl Siegfried Guthke}

Conrad, Joseph 1993. The Heart of Darkness. London: Random House.

Conrad, Joseph 2002. Pimeduse süda: Romaan. Tõlk Riina Jesmin. Tallinn: Varrak.

Conroy, Frank 1993. Body and Soul. Boston: Houghton Mifflin \& Seymour Lawrence.

Cooper, Gary 1992. The Man Who Sank the Titanic? The Life and Times of Captain Edward J. Smith. Stoke-On-Trent: Witan.

Courtois, Martine 1991. Les mots de la mort. Le français retrouvé 23. Pariis: Belin.

Cutright, Paul Russell \& Brodhead, Michael J. 1981. Elliott Coues: Naturalist and Frontier Historian. Urbana \& London: University of Illinois Press.

Feifel, Herman (toim) 1959. The Meaning of Death. New York: Blakiston Division \& McGraw-Hill.

Le Figaro 1998, 4. september.

Figes, Orlando 1998. The Russia of the Mind. Times Literary Supplement, 5. juuni, lk 14.

Flanner, Janet 1988. Paris was Yesterday: 1925-1939. San Diego: Harcourt Brace Jovanovich.

Focus 1994, 8. august.

Foucart, François 1998. L'Affaire Omar Raddad. Paris: Guibert.

Foxworthy, Jeff 1996. No shirt. No shoes - no problem! New York: Hyperion.

Fraser, Antonia (toim) 1975. The Lives of the Kings and Queens of England. London: Weidenfeld \& Nicolson.

Garland, Alex 1996. Beatch. London: Viking.

Garland, Alex 2000. Rand. Tõlk Rein Turu. Tallinn: Varrak.

Gatrell, V.A. C. 1996. The Hanging Tree: Execution and the English People, 1770-1868. New York: Oxford University Press.

Geyer, Georgie Anne 1994. Waiting for Winter to End: An Extraordinary Journey Through Soviet Central Asia. Washington \& London: Brassey's.

Goethe, Johann Wolfgang von 1986. Faust. Bibliothek der Weltliteratur. Berlin \& Weimar: Aufbau-Verlag.

Goethe, Johann Wolfgang von 1972. Faust. Tõlk August Sang. Kooli kirjavara. Tallinn: Eesti Raamat.

Guthke, Karl Siegfried 1990. Letzte Worte: Variationen über ein Thema der Kulturgeschichte des Westens, München: Beck, lk 35-55. 


\section{Karl Siegfried Guthke}

Guthke, Karl Siegfried 1992. Last Words: Variations on a Theme in Cultural History. Princeton (New Jersey): Princeton University Press.

Guthke, Karl Siegfried 1993a. Life from the End. Gutke, Karl S. Trails in No-Man's Land: Essays in literary and cultural history. Columbia (S.C.): Camden House, lk 200-216.

Guthke, Karl Siegfried 1993b. Life from the End. Guthke, Karl S. Die Entdeckung des Ich:Studien zur Literatur. Edition Orpheus 8. Tübingen [et al.]: Francke, lk 290-307.

Harper's Bazaar 1941, oktoober.

Harvard Crimson 1995, 20. aprill.

The Harvard Lampoon 1995, CLXXXV.

Hebbel, Christian Friedrich 1908. Tagebücher II. Hebbels Werke in Teilen 10. Theodor Poppe (koost). Berlin [et al.]: Deutsches Verlagshaus Bong.

Hoffmann, Yoel (koost) 1986 (7. tr 1998). Japanese Death Poems. Rutland (Vermont) \& Tokio: Charles E. Tuttle Co.

Hofmannstahl, Hugo von 1982. Dramen 1. Sämtliche Werke: Kritische Ausgabe 3. Götz Eberhard Hübner (koost). Frankfurt am Main: Fischer.

Houlbrooke, Ralph Anthony 1998. Death, Religion and the Family in England, 1480-1750. Oxford: Oxford University Press.

Hunter, William Bridges jun (koost ja toim) 1963. The Complete Poetry of Ben Jonson. Stuart editions. New York: New York University Press.

Ignatieff, Michael 1998. Isaiah Berlin: A life. London: Chatto \& Windus.

Jalland, Patricia 1996. Death in the Victorian Family. Oxford: Oxford University Press.

Jürger, Ernst 1980 jj. Siebzig verweht. 10. jaan 1977; 28. juuni 1987; 22. jaanuar 1990. Stuttgart: Klett-Cotta.

Jünger, Ernst 1981. Siebzig verweht 2. Stuttgart: Klett-Cotta.

Kane, Joseph Nathan 1981. Facts About the Presidents: A compilation of biographical and historical information. 4. tr. New York: Wilson.

Kaplan, Edward K. (tõlk) 1984. Mother Death: The Journal of Jules Michelet, 1815-1850. Amherst (Massachusetts): University of Massachusetts Press.

Kunert, Günter (koost) 1996. Mein Golem: Gedichte. München [et al.]: Hanser.

Lawrence, David Herbert 1978. The Reality of Peace. Warren Roberts \& Harry T. Moore (koost ja toim). Phoenix II: Uncollected, unpublished, and other prose works. Harmondsworth \& New York: Penguin Books.

Le Comte, Edward 1955. Dictionary of Last Words. Mid-century reference library. New York: Philosophical Library. 


\section{Karl Siegfried Guthke}

The London Review of Books 1998, 3. september; 15. oktoober.

Machtan, Lothar 1998. Bismarcks Tod und Deutschlands Tränen: Reportage einer Tragödie. München: Goldmann.

Mackay, Margaret Mackprang 1963. Angry Island: The Story of Tristan da Cunha, 1506-1963. London: Arthur Barker.

Malcolm, Norman 1958. Ludwig Wittgenstein: A Memoir. London: Oxford University Press.

Malcolm, Norman 1984. Ludwig Wittgenstein: A Memoir. Oxford (Oxfordshire) \& New York: Oxford University Press.

Maugham, William Somerset 1941. Ashenden, or the British agent. Garden City (New York): Doubleday, Doran \& company, Inc.

Mayhew, Vic (koost) \& Bulpin, Thomas Victor (teksti autor) 1993. Reader's Digest Illustrated Guide to Southern Africa. Cape Town: Reader's Digest Association South Africa.

McPhee, John 1993. Cargo. Tõlk Hans J. Schütz. Stuttgart: Klett-Cotta.

McPhee, John A.1990. Looking for a ship. New York: Farrar Straus Giroux.

Meyers, Jeffrey 1980. The Enemy: A Biography of Wyndham Lewis. Boston (Mass.) \& London: Routledge \& Kegan Paul.

National Enquirer 1994, 13. detsember.

National Geographic 1974, aprill.

Nette, Herbert 1983. Hier kann ich doch nicht bleiben: Eine Sammlung letzter Worte. München: Deutsche Taschenbuch-Verlag.

Neue Züricher Zeitung 1992, 16. september.

The New Republic 1998, 14. detsember.

New York Times 1990, 16. september; 1991, 22. juuli; 1992, 22. juuli; 1993, 6. jaanuar, 16. veebruar, 15. aprill; 1994, 26. aprill, 18. mai, 31. juuli, 1. august, 22. august, 9 november; 1995, 1. jaanuar, 28. jaanuar, 21. märts, 23. märts, 28. aprill, 27. juuli, 2. august, 1996, 20. märts, 1 . juuni, 15. juuli, 18. juuli, 20. juuli, 8. august, 23. august, 27. august, 7. september, 24. september, 27. november; 1997, 10. jaanuar, 27. veebruar, 26. märts, 29. märts, 27. detsember, 1998, 4. veebruar, 15. veebruar, 14. november.

New York Times Book Review 1995, 16. aprill.

New Yorker 1995, 1. mai.

Newsweek 1987, 21. september; 1990, 12. veebruar, 29. oktoober; 1994, 26. detsember (kuni 2. jaanuar 1995); 1995, 16. jaanuar.

Nietzsche, Friedrich Wilhelm 1949. Vom Nutzen und Nachteil der Historie für das Leben. Basel: Birkhäuser. 


\section{Karl Siegfried Guthke}

O'Kill, Brian 1986. Exit Lines: Famous (and not-so-Famous) Last Words. Harlow (Essex): Longman.

Oberreuter-Kronabel, Gabriele 1986. Der Tot des Philosophen: Unters. zum Sinngehalt e. Sterbebildtypus d. franz. Malerei i.d. 2. Hälfte d. 18. Jh. München: Fink.

Olds, Clifton Cooper 1966. Ars Moriendi: A Study of the Form and Content of Fifteenth Century Illustrations of the Art of Dying. Dissertation. University of Pennsylvania.

Parth, Wolfgang W. 1981. Die letzten Worte. Parth, Wolfgang W. Geschichten von Herrn Goethe. München: Kindler.

People 1994, 28. märts.

People [Magazine] Online Daily 1998, 19. mai (http://www.pathfinder.com/ people/daily/98back/980519.html - 4. mai 2004).

Poznansky, Alexander 1996. Tchaikovsky's last days: A documentary study. Oxford: Clarendon Press.

Reich-Ranicki, Marcel 1986. Frankfurter Anthologie: Gedichte und Interpretationen 10. Frankfurt am Main [et al.]: Insel-Verlag.

Ritter, Johann Wilhelm 1810. Fragmente aus dem Nachlaß eines jungen Physikers: Ein Taschenbuch für Freunde der Natur. Heidelberg: Mohr \& Zimmer.

Rodríguez Monegal, Emir 1978. Jorge Luis Borges: A Literary Biography. New York: Dutton.

Ruffin, Caulbert Bernard 1995. Last Words: A dictionary of deathbed quotations. Jefferson (Põhja-Carolina): McFarland.

Sammlung der Leichenpredigten = Katalog der Leichenpredigten der Herzog August Bibliothek in Wolfenbüttel (vt http://avanti.hab.de/hab_db/lpx/html/ start_ger.html - 7. aprill 2004).

Schelling, Friedrich Wilhelm Joseph von 1856. Friedrich Wilhelm Joseph von Schellings sämmtliche Werke 1: 1. Stuttgart et al.: Cotta.

Schiller, Friedrich 1924. Die Kraniche des Ibykus. Friedrich von Schiller's Balladen für estnische Schulen 1. Tartu: Elmar Kikas.

Schiller, Friedrich 1959. Ballaade. Tõlk Ain Kaalep. Tallinn: Eesti Riiklik Kirjastus.

Schiller, Friedrich 1960. Röövlid: Näidend. Tõlk Jaan Kärner. Tallinn: Eesti Riiklik Kirjastus.

Schiller, Friedrich 1962. Die Räuber: Schauspiel in fünf Akten. UniversalBibliothek 15. Stuttgart: Reclam. 


\section{Karl Siegfried Guthke}

Schiller, Friedrich 1993. Wallenstein: Ein dramatisches Gedicht 1: Wallensteins Lager. Die Piccolomini. Leipzig: Reclam.

Schiller, Friedrich 1994. Wallenstein: Ein dramatisches Gedicht 2: Wallensteins Tod. Reclams Universal-Bibliothek 42. Stuttgart: Reclam.

Schoeps, Hans Joachim 1971. Ungeflügelte Worte: Was nicht im Büchmann stehen kann. Berlin: Haude \& Spener.

Schwilk, Heimo 1988. Ernst Jünger: Leben und Werk in Bildern und Texten. Stuttgart: Klett-Cotta.

Scott, Dorsey 1992. Famous Last Words. New York: Carleton Press.

Scott-Giles, Charles Wilfrid 1975. Sidney Sussex College: A Short History. Cambridge: [Sidney Sussex College].

Sepúveda, Luis 1996. Full Circle: A South-American Journey. Tõlk Chris Andrews. Melbourne \& London: Lonely Planet.

Sinden, Donald 1994. The Last Words: A sparkling collection of put-downs, epitaphs, final utterances, touching tributes and damning dismissals. London: Robson.

Sitwell, Sacheverell 1953. Truffle Hunt: [Essays on various subjects]. London: Robert Hale.

Spender, Stephen 1951. World Within World: The autobiography. London: H. Hamilton.

Spufford, Francis 1997. May be Some Time: Ice and the English imagination. New York: St. Martin's Press.

Strachey, Lytton 1931. The Sad Story of Dr. Colbatch. Strachey, Lytton. Portraits in Miniature and other essays. London: Chatto \& Windus.

Strauß, Botho 1981. Paare, Passanten. München: Hanser.

Süskind, Patrick 1985. Das Parfum: Die Geschichte eines Mörders. Zürich: Diogenes.

Zeit 1997, 29. august.

Zeit-Magazin 1999, 28. jaanuar, 11. märts, 6 mai.

Taylor, Alan John Percivale 1974. Bismarck, the Man and the Statesman. London: New English Library.

Teitelboim, Volodia 1991. Neruda. 4. tr. Santiago de Chile: Ediciones Bat. Thomson, David 1996. Rosebud: The story of Orson Welles. New York: Alfred A. Knopf.

Times 2. mai 1994.

Times [London] 1992, 13. detsember; 1994, 2. veebruar; 1998, 19. august. 


\section{Karl Siegfried Guthke}

Times Literary Supplement 1994, 5. august; 1995, 6. oktoober.

TV Quick 1992, 7.-13. november.

U. S. News and World Report $1991=$ U. S. News and World Report:America's Best Colleges. Washington (Columbia ringkond): U. S. News \& World Report. Ueding, Gert (koost) 1987. Karl-May-Handbuch. Stuttgart: Kröner.

Updike, John 1995. Rabbit Angstrom: A tetralogy. Everyman's library 214. London: David Campbell Publishers.

Vickers, Hugo 1985. Cecil Beaton: A Biography. Boston: Little \& Brown.

Weekly World News 1991, 5. veebruar.

What's on TV? 1998, 1.-7. august.

White, Elwin Brooks 1979. Charlotte koob võrku. Tõlk Piret Saluri, Enn Soosaar, Paul-Eerik Rummo. Tallinn: Eesti Raamat.

Woodall, James 1996. The man in the mirror of the book: A Life of Jorge Luis Borges. London: Hodder \& Stoughton. 